\title{
Regional disparities in labor market performance in Croatia: The role of individual and regional structural characteristics
}

\author{
Xubei Luo
}

\begin{abstract}
:
The labor market performance in Croatia failed to keep pace with the moderately good overall macroeconomic development in the last few years. Youth, the less well-educated, and women face more difficulties in getting a job with a decent salary. A large part of the difference in regional labor market performance is associated with the difference in the human capital endowment. With a stagnant total employment rate, the large disparities in employment and earnings across individual groups and regions have become one of the concerns for the long-term sustainable development of the economy.

Using Labor Force Survey (LFS) data from 2002-2004, this paper studies the labor market performance in Croatia at the national and regional levels. The results show that both one's individual characteristics (including age, education and gender) and where he or she works plays a role in his or her employment and earnings. Regional differences in employment and earnings are reduced to a large extent when accounting for differences in individual characteristics. The simulations shed light on the effectiveness of the nation-wide education policy and regional specific labor market policy, and suggest that improving human capital endowment and adjusting labor market structure are both important to rebalance regional development and enhance total welfare.
\end{abstract}

Key words: Employment; Labor market performance; Return on education.

JEL classification: R23, J31, J71

World Bank Policy Research Working Paper 4148, March 2007

The Policy Research Working Paper Series disseminates the findings of work in progress to encourage the exchange of ideas about development issues. An objective of the series is to get the findings out quickly, even if the presentations are less than fully polished. The papers carry the names of the authors and should be cited accordingly. The findings, interpretations, and conclusions expressed in this paper are entirely those of the authors. They do not necessarily represent the view of the World Bank, its Executive Directors, or the countries they represent. Policy Research Working Papers are available online at http://econ.worldbank.org. 


\title{
Regional disparities in labor market performance in Croatia: The role of individual and regional structural characteristics
}

\author{
Xubei Luo*
}

The labor market performance in Croatia failed to keep pace with the moderately good overall macroeconomic development in the last few years. With a stagnant total employment rate, the large disparities in employment and earnings across individual groups and regions have become one of the concerns for the long-term sustainable development of the economy.

Using Labor Force Survey (LFS) data from 2002-2004, this paper studies the labor market performance in Croatia at the national and regional levels. The results show that both one's individual characteristics (including age, education and gender) and where he or she works plays a role in his or her employment and earning. The regional difference in employment and earnings is reduced to a large extent when the difference in individual characteristics is accounted for. The simulations shed light on the effectiveness of the nation-wide education policy and regional specific labor market policy, and suggest that improving human capital endowment and adjusting labor market structure are both important to rebalance regional development and enhance total welfare.

The paper is structured as follows. The first section describes the labor market performance in Croatia, and presents the disparities across individual groups and regions. The second section studies the determination of employment and earnings at the national and regional levels, and examines the role of the individual characteristics and regional structural characteristics. The third section simulates the effects of the nation-wide education policy and regional specific labor market policy on labor market development. The final section concludes.

\section{Labor market performance in Croatia}

The economy of Croatia has been growing quite satisfactorily in the period of 2002-2004 with a GDP growth rate of $4.4 \% .{ }^{1}$ However, the labor market performance was stagnant only $55 \%$ of the working-age population was employed, which lagged far behind the employment objective of the Lisbon Agenda. The fruits of economic growth were not shared equally across the society - although wage increased slightly in nominal terms, with a long-term unemployment rate of about $60 \%,{ }^{2}$ a large percentage of the active

\footnotetext{
* The author is indebted to Jean-Jacques Dethier, Bernard Funck, Chorching Goh, Gillmore Hoefdraad, Satu Kristiina Kahkonen, Tracey Lane, Paula Lytle, Sanja Madzarevic-Sujster, Celestin Monga, Russell Pittman, Sarosh Sattar, and Salman Zaidi for helpful comments.

${ }^{1}$ Data source: Central Bureau of Statistics and Croatian Pension Insurance Fund, cited from Nestic (2006)

${ }^{2}$ Long-term unemployment rate is measured as the share of the unemployed population who are unemployed for at least 12 months.
} 
population was not able to be fully integrated / re-integrated into the society. The poverty rate stayed around $11 \%{ }^{3}$

There exist large disparities across region / counties and individual groups. Other things being equal, the individuals living in the Central and Eastern regions suffered disproportionately. In 2003, the GDP per capita of the richest county, City of Zagreb, was about three times that of the poorest county, county of Slavonski Brod-Posavina. ${ }^{4}$ The employment rate varies among the 21 counties, from less than $43 \%$ (County of VukovarSirmium) to almost $70 \%$ (County of Krapina-Zagorje). Within many counties, the labor market performance differs at a more disaggregate level - for example, the county of Lika-Senj, the problem of unemployment is much more serious in the inland area than in the coastal area. Youth, the less educated, and women face more difficulties in the labor market. The unemployment rate of youth (15-25 years old) was three times that of the other working-age groups. The earnings level of the individuals with tertiary education is at least twice that of the individuals with basic education or less. Women face harder time in securing a job and in having a good salary compared with man...

\subsection{Limited change in labor market performance at the national level}

The Croatian labor market performance is lagging behind many EU countries. The employment rate in Croatia ${ }^{5}$, which is about $55 \%$, is $20 \%$ below the Lisbon target, which is $70 \%$ (graph 1). The average employment rate of the EU 25 countries in 2002-2004 is about $63 \%$, and that of the EU 15 countries is $64.5 \%{ }^{6}$

\section{Graph 1: Total employment rate of EU countries (2002-2004)}

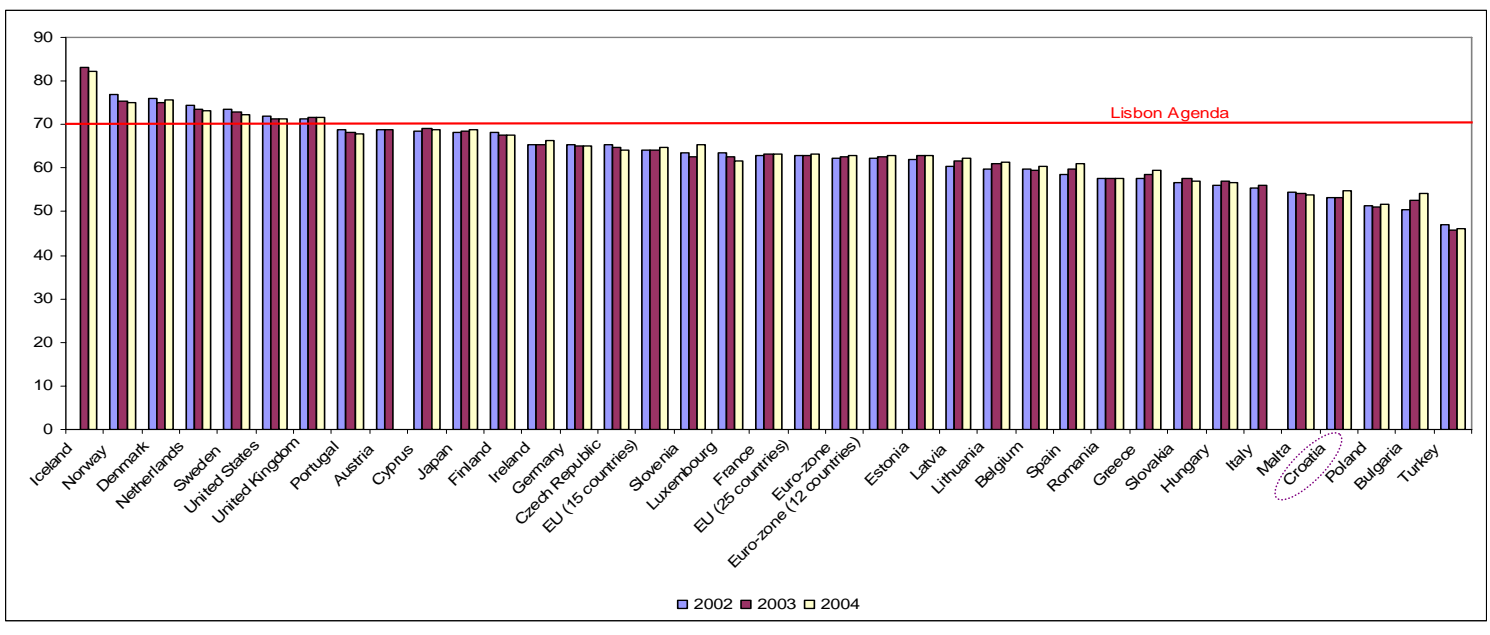

\footnotetext{
${ }^{3}$ The poverty rate is subject to the poverty line of yearly consumption of 22145 kuna per equivalent adult. See Nestic (2006) for further discussion.

${ }^{4}$ Data source: Lovrincevic and Mikulic (2006)

${ }^{5}$ Based on the LFS questionnaires, employment is defined as the working-age population who worked for at least an hour in the reference week or had a job to return to if they did not work in the reference week.

${ }^{6}$ Data source: Eurostat statistics. Website:

http://epp.eurostat.cec.eu.int/portal/page?_pageid=1996,39140985\&_dad=portal\&_schema=PORTAL\&scr een $=$ detailref\&language $=$ en $\&$ product $=$ sdi_ed\&root $=$ sdi_ed $/$ sdi_ed $/ \mathbf{s d i}$ _ed_emp/sdi_ed 1400
} 
The labor market performance in Croatia did not change much in the recent years. ${ }^{7}$ Based on the LFS data, about $65 \%$ of the working-age population (15-65 years old) participated in the labor force, of which $55 \%$ were employed. Despite the relatively strong overall macroeconomic performance, the unemployment rate in Croatia, according to the definition of the International Labor Organization (ILO), ${ }^{8}$ hovered around $14-15 \%$ (table $1)$.

\section{Table 1: Labor force participation rate, employment rate, and ILO unemployment rate in Croatia (2002-2004)}

\begin{tabular}{ccccccc}
\hline \hline & \multicolumn{2}{c}{ Labor force participation rate } & \multicolumn{2}{c}{ Employment rate } & \multicolumn{2}{c}{ ILO unemployment rate } \\
& $\begin{array}{c}\text { mean } \\
\text { value }\end{array}$ & $\begin{array}{c}95 \% \text { confidence } \\
\text { interval }\end{array}$ & $\begin{array}{c}\text { mean } \\
\text { value }\end{array}$ & $\begin{array}{c}95 \% \text { confidence } \\
\text { interval }\end{array}$ & $\begin{array}{c}\text { mean } \\
\text { value }\end{array}$ & $\begin{array}{c}95 \% \text { confidence } \\
\text { interval }\end{array}$ \\
\hline 2002 & $64.88 \%$ & {$[64.09 \%-65.66 \%]$} & $53.94 \%$ & {$[53.15 \%-54.72 \%]$} & $15.04 \%$ & {$[14.36 \%-15.72 \%]$} \\
2003 & $64.73 \%$ & {$[63.85 \%-65.62 \%]$} & $54.13 \%$ & {$[53.25 \%-55.00 \%]$} & $14.51 \%$ & {$[13.74 \%-15.28 \%]$} \\
2004 & $65.90 \%$ & {$[65.05 \%-66.75 \%]$} & $55.36 \%$ & {$[54.55 \%-56.17 \%]$} & $13.98 \%$ & {$[13.30 \%-14.67 \%]$} \\
\hline \hline
\end{tabular}

Note: According to the International Labor Organization, the labor force participation rate is a measure of the proportion of a country's working-age population that engages actively in the labor market, either by working or looking for work; the employment rate (employment-to-population ratio) is defined as the proportion of a country's working-age population (15-65) that is employed. The unemployment rate is defined as the proportion of the labor force (working-age population that is employed or unemployed) that does not have a job and is actively looking for work.

For the individuals who are employed, the distribution of their monthly earnings (in kuna) also stayed relatively stable in the period of 2002-2004, although the mean level in nominal terms increased slightly (graph 2). ${ }^{9}$ More than $90 \%$ of the individuals employed have a monthly earnings level of less than 5000 kuna. The relatively high density of the

\footnotetext{
${ }^{7}$ The unemployment rate in Croatia did not change much since the late 1990s (Rutkowski, 2002). Although the mean level of employment rate increases / unemployment rate decreases slightly in the period of 20022004, the changes are not significant in statistical senses.

${ }^{8}$ The ILO unemployment rate, based on the LFS carried out by the Croatian Bureau of Statistics, is lower than the administrative unemployment data, which is maintained by the Croatia Employment Service. According to the statistics of the Central Bureau of Statistics and Croatian Pension Insurance Fund, the registered unemployment rate was around $20 \%$ in 2002-2004. The administrative data are affected by the incentive to register as "unemployed". On the one hand, some persons may register as unemployed in order to be eligible to unemployment benefits, pension, health insurance, and social assistance benefits, although they are not genuinely unemployed; on the other hand, the persons who are genuinely unemployed may not register if they are not eligible for the benefits associated wit the registration (Rutkowski, 2002). Overall, the administrative data may overestimate the actual magnitude of unemployment. In this study, we use the LFS data and follow the ILO unemployment definition.

${ }^{9}$ Based on the LFS questionnaires, earnings is measured as the usual net monthly earnings/salary on the main job in kuna. In Croatia, the average level of monthly earnings is around 3013 kuna, 3205 kuna, and 3326 kuna respectively in 2002, 2003, and 2004 in nominal terms. In this study, we examine the determination of employment and earnings of the individuals with positive earnings reported. The analysis may be subject to the three data constraints: 1 . For individuals who are employed with more than one job, their monthly earnings reported might under-represent the real income. 2. We have to neglect the individuals without positive earnings although they are reported as employed in the survey, which represent about $5 \%$ of the population employed. 3 . No further information on in kind income is available from the survey. In this paper, all labor market indicators are measured for the individuals who are in the working age, and based on the LFS 2002-2004 data if not otherwise specified. We interchangeably use the wordings "wage" and "earning".
} 
distribution at the lower end may partly be resulted from the high incidence of the lowpaid jobs.

\section{Graph 2: Distribution of nominal monthly earnings of the individuals who are employed} (2002-2004)

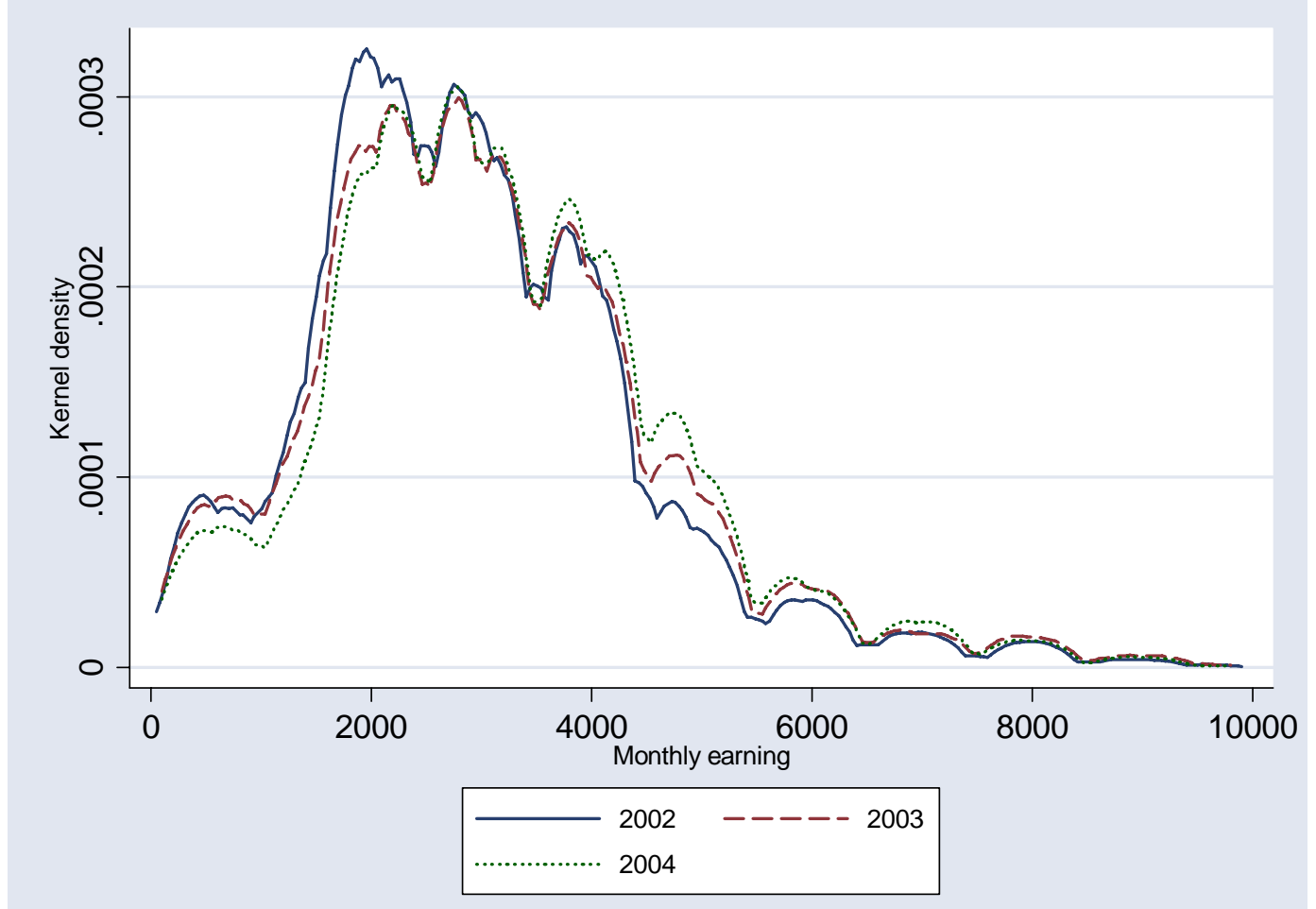

Note: For practical purposes, we exclude the observations with extreme values of monthly earnings (monthly earnings $>15000$ kuna), which represent less than $0.2 \%$ of the total sample.

\subsection{Large differences in labor market opportunities across individual groups}

In order to increase the number of observations, we pool the six rounds of the LFS data 2002-2004 ${ }^{10}$ together, given significant changes of labor market performance in Croatia were absent in 2002-2004. We use the pooled data as if they were a single sample from a larger survey, fielded over a longer period, given each consecutive round's sample in LFS can be considered as a random, equal-probability sub-sample of a larger sample taken in a single instance for the period as a whole for all practical purposes. ${ }^{11} \mathrm{We}$ find that, in 2002-2004, the key indicators, such as employment rate / unemployment rate and earnings level, differ largely across age groups, education groups, gender, and regions.

The youth group has the lowest employment rate/highest unemployment rate among other working-age population - the employment rate of the individuals who are 15-25 years old is less than $25 \%$, which represents only a third of the employment rate of the

${ }^{10}$ The LFS were implemented in two six-month rounds each calendar year in 2002-2004.

${ }^{11}$ See Munoz (2006) for the rational and techniques of data pooling. 
individuals who are 25-50 years old; similarly, the unemployment rate of the individuals who are 15-25 years old is three times that of the age group 25-50 (table 2). Youth employment rate in Croatia is about twice of the EU average. ${ }^{12}$ Croatian youth who manage to find a job also suffer from low earnings - in average, the youth who are employed earn less than 2500 kuna per month, which is roughly 1000 kuna (or 30\% in relative terms) less than those who are 25 years or older. With a high unemployment rate and a low earnings level, the youth in Croatia face a particularly difficult situation.

Table 2: Employment rate, unemployment rate and monthly earnings by age groups in Croatia (2002-2004)

\begin{tabular}{lccc}
\hline Age range & Employment rate & ILO unemployment rate & Monthly earnings (kuna) \\
\hline$(15,25)$ & $24.87 \%$ & $35.93 \%$ & 2449 \\
{$[25,50)$} & $72.41 \%$ & $12.86 \%$ & 3316 \\
{$[50,65)$} & $42.05 \%$ & $8.47 \%$ & 3463 \\
\hline
\end{tabular}

As in many other countries, the individuals in Croatia with better education have higher probabilities to get employed, and the earnings level monotonically increases with their levels of schooling (table 3 ). The individuals with tertiary education not only have lower unemployment rate than those with less education, but also have a much higher earnings level if they get employed. For example, the unemployment rate of the individuals with university education and above is about $7.5 \%$, and that of the individuals with basic education is $16 \%$. The earnings level of the individuals with university education and above is in average three times that of the individuals with no school or uncompleted basic education, and about $70 \%$ higher than the individuals with lower secondary vocational education. ${ }^{13}$

Table 3: Employment rate, unemployment rate and monthly earnings by education groups in Croatia (2002-2004)

\begin{tabular}{lccc}
\hline & $\begin{array}{c}\text { Employment } \\
\text { rate }\end{array}$ & $\begin{array}{c}\text { Unemployment } \\
\text { rate }\end{array}$ & $\begin{array}{c}\text { Monthly } \\
\text { earnings } \\
\text { (kuna) }\end{array}$ \\
\hline No school or uncompleted basic education & $30.79 \%$ & $12.47 \%$ & 1675 \\
Basic education & $37.02 \%$ & $16.05 \%$ & 2256 \\
Lower secondary vocational education & $61.56 \%$ & $16.03 \%$ & 3115 \\
Higher secondary education & $31.68 \%$ & $17.52 \%$ & 3247 \\
Two-year post secondary education & $73.50 \%$ & $8.69 \%$ & 4313 \\
University education and above & $82.80 \%$ & $7.46 \%$ & 5252 \\
\hline
\end{tabular}

\footnotetext{
${ }^{12}$ According to the Eurostat statistics of "total unemployment rate by age group", in 2002-2004, the average youth unemployment rate of the EU 25 countries is $18.7 \%$ and the EU 15 countries is $16.6 \%$. Website http://epp.eurostat.cec.eu.int/portal/page?_pageid=1996,39140985\&_dad=portal\&_schema=PORTAL\&scr een $=$ detailref\&language $=$ en\&product $=$ sdi_ed\&root $=$ sdi_ed/sdi_ed/sdi_ed_emp $/ \mathbf{s d i}$ _ed 1432

${ }^{13}$ The low employment rate/high unemployment rate of the individuals with "high secondary education" (grammar school) may be linked to their low participation rate, which is less than $40 \%$ compared with 70 $90 \%$ of the other individuals with secondary education and above. They represent less than $4 \%$ of the working-age population.
} 
Gender is also an important dimension of inequality in Croatia. Women have a lower participation rate, a lower employment rate/ a higher unemployment rate, and lower monthly earnings than men (table 4).

Table 4: Employment rate, unemployment rate and monthly earnings by gender in Croatia (2002-2004)

\begin{tabular}{lcccc}
\hline & $\begin{array}{c}\text { Labor force } \\
\text { participation rate }\end{array}$ & Employment rate & Unemployment rate & $\begin{array}{c}\text { Monthly earnings } \\
\text { (kuna) }\end{array}$ \\
\hline Men & $71.91 \%$ & $61.35 \%$ & $12.96 \%$ & 3514 \\
Women & $58.63 \%$ & $47.80 \%$ & $16.36 \%$ & 2978 \\
\hline
\end{tabular}

\subsection{Disparities in labor market performance at the regional and county levels}

The variation of employment rate, unemployment rate, and earnings level across age groups, education groups, and gender suggests that the opportunities in labor market that an individual faces is associated with his or her individual characteristics. However, the disparities in employment and earning, as those in GDP per capita, are also large across counties / regions in Croatia.

Following the regional divides in the 1998 Living Standards Assessment (World Bank, 2000), the 21 counties in Croatia is grouped into 5 regions for analytical purposes as follows ${ }^{14}$ :

Region 1 - Central Region: Krapina-Zagorje, Sisak-Moslavina, Karlovac, Varazdin, Koprivnica-Krizevci, Bjelovar-Bilogora and Medimurje.

Region 2 - Eastern Region: Virovitica-Podravina, Pozega-Slavonia, Slav. Brod-Posavina, Osijek-Baranja, and Vukovar-Sirmium.

Region 3 - Zagreb Region: Zagreb County and Zagreb City.

Region 4 - Adriatic North Region: Primorje-Gorski kotar, Lika-Senj, and Istria.

Region 5 - Adriatic South Region: Zadar, Sibenik-Knin, Split-Dalmatia and DubrovnikNeretva.

The human capital endowment, measured by years of school or highest attained level of schooling $^{15}$, varies across regions. The graph 3 shows that the Central Region and Eastern Region have a higher percentage (about $40 \%$ ) of working-age population with "no school or uncompleted basic education" or "basic education" compared with the other three regions (about 25\%). Zagreb region has a disproportionately high percentage of workingage population with university education and above. Both indicators of education, "level of schooling" and "years of school", indicate that the Central Region and Eastern region are the least well endowed in human capital.

\footnotetext{
${ }^{14}$ See Appendix.

${ }^{15}$ In the following sections, we simply call the "highest attained level of schooling" as the "level of schooling".
} 
Graph 3: Distribution of human capital by region (2002-2004)

Graph 3A: Level of schooling

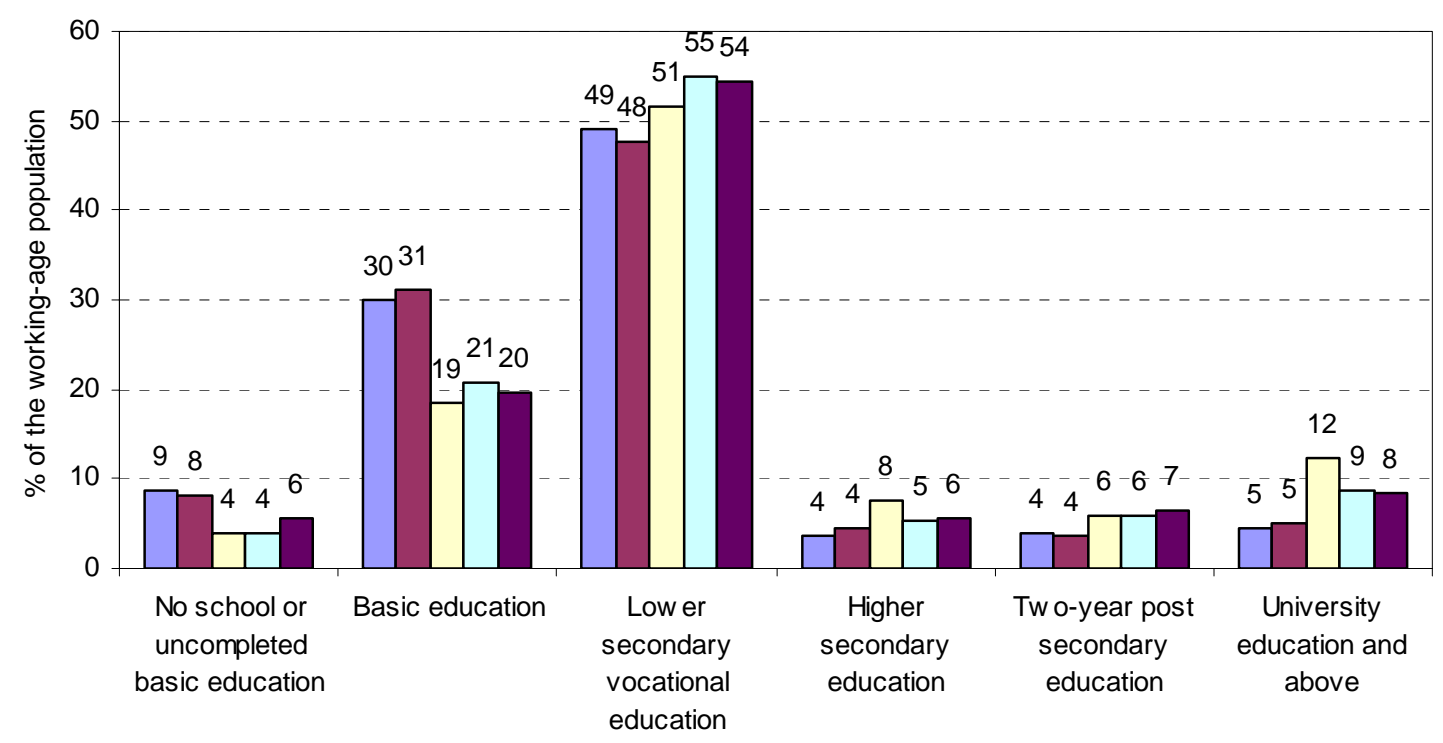

$\square$ Central Region $\square$ Eastern Region $\square$ Zagreb Region $\square$ Adriatic North Region $\square$ Adriatic South Region

\section{Graph 3B: Years of School}

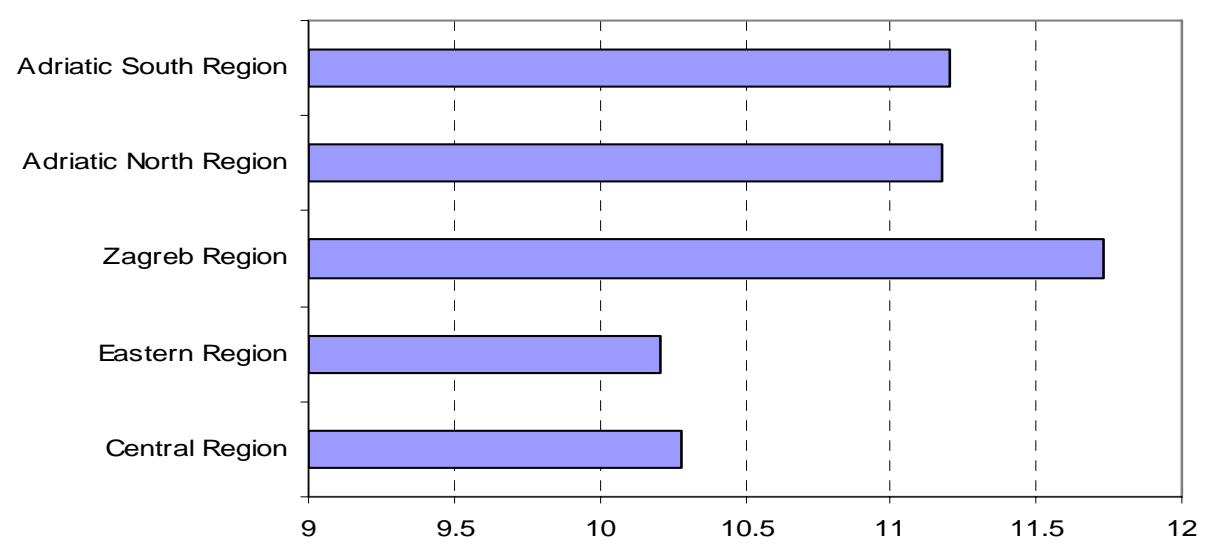

The Zagreb Region is in a leading position (table 5) in two dimensions, including human capital endowment and earnings level. The Eastern region, however, is lagging behind in many aspects, including a less satisfactory human capital endowment, a low employment rate / a high unemployment rate, and a low earnings level. Although the participation rate and employment rate are high in the Central Region, the earnings level and human capital endowment are low. Adriatic North Region and Adriatic South Region have similar levels of earnings and human capital, which are both slightly lower than those in the Zagreb Region, but the employment rate is lower in the Adriatic South Region. 
Table 5 -- Summary statistics on labor market indicators by region in Croatia (2002-04)

\begin{tabular}{lccccc}
\hline & $\begin{array}{c}\text { Active } \\
\text { population } \\
\text { rate }\end{array}$ & $\begin{array}{c}\text { Participation } \\
\text { rate }\end{array}$ & $\begin{array}{c}\text { Employment } \\
\text { rate }\end{array}$ & $\begin{array}{c}\text { Unemployment } \\
\text { rate }\end{array}$ & $\begin{array}{c}\text { Monthly } \\
\text { earnings } \\
\text { (kuna) }\end{array}$ \\
\hline Central Region & $63.90 \%$ & $72.30 \%$ & $60.81 \%$ & $11.47 \%$ & 2806 \\
Eastern Region & $63.00 \%$ & $61.11 \%$ & $47.86 \%$ & $19.93 \%$ & 2826 \\
Zagreb Region & $66.09 \%$ & $63.56 \%$ & $55.91 \%$ & $11.84 \%$ & 3735 \\
Adriatic North Region & $64.38 \%$ & $66.06 \%$ & $58.47 \%$ & $9.92 \%$ & 3498 \\
Adriatic South Region & $62.28 \%$ & $62.22 \%$ & $48.94 \%$ & $20.23 \%$ & 3524 \\
\hline Croatia & $64.01 \%$ & $65.17 \%$ & $54.47 \%$ & $14.51 \%$ & 3276 \\
\hline
\end{tabular}

Although regions differ from each other, there is significant heterogeneity between counties within regions. The active population rate, the participation rate, the employment rate / unemployment rate, the mean monthly earning, and the mean level of years of school vary across counties within each region to a different extent (table 6).

- On employment rate - three (out of a total of five) counties, including VukovarSirmium, Slav. Brod-Posavina, and Osijek-Baranja, in the Eastern Region are among the four counties with the lowest employment rate (below 48\%), while the county of Virovitica-Podravina, with an employment rate of $58 \%$, has a higher employment rate than all counties in Zagreb Region and Adriatic South Region. Five (out of a total of seven) counties, including Krapina-Zagorje, Varazdin, Bjelovar-Bilogora, Koprivnica-Krizevci, and Medimurje, in the Central Region are among the six counties with the highest employment rate (above 59\%), while the county of Sisak-Moslavina, with an employment rate of $51 \%$, ranks below all counties in the Zagreb Region and the Adriatic North Region and some counties in the Eastern Region.

- On earnings level - all 11 counties with the lowest monthly earnings level are in the Eastern Region and the Central Region. The average monthly earnings of the City of Zagreb is almost $20 \%$ higher than the national average.

- On years of school - seven out of eight counties, except the county of Lika-Senj, with the lowest human capital endowment (lower than nine years of school) are in the Eastern Region and the Central Region. All four counties with average education higher than ten years of school are in the Zagreb Region, the Adriatic North Region, and the Adriatic South Region.

- There is a strong correlation (over 0.8 ) between years of school and level of earnings for the 21 counties. 
Table 6 -- Summary statistics on labor market indicators by county in Croatia (2002-04)

\begin{tabular}{clcccccc}
\hline & \multicolumn{1}{c}{ County } & $\begin{array}{c}\text { Active } \\
\text { population } \\
\text { rate }\end{array}$ & $\begin{array}{c}\text { Participa- } \\
\text { tion rate }\end{array}$ & $\begin{array}{c}\text { Employ } \\
\text {-ment } \\
\text { rate }\end{array}$ & $\begin{array}{c}\text { Unemploy } \\
\text {-ment rate }\end{array}$ & $\begin{array}{c}\text { Monthly } \\
\text { earnings } \\
\text { (kuna) }\end{array}$ & $\begin{array}{c}\text { Years of } \\
\text { school }\end{array}$ \\
\hline 1 & County of Zagreb & $65.36 \%$ & $62.27 \%$ & $52.91 \%$ & $14.78 \%$ & 3319 & 9.63 \\
2 & County of Krapina-Zagorje & $63.89 \%$ & $82.04 \%$ & $69.62 \%$ & $4.89 \%$ & 3012 & 8.68 \\
3 & County of Sisak-Moslavina & $62.94 \%$ & $64.07 \%$ & $50.70 \%$ & $18.98 \%$ & 3084 & 9.10 \\
4 & County of Karlovac & $61.30 \%$ & $70.73 \%$ & $57.12 \%$ & $15.53 \%$ & 2967 & 9.13 \\
5 & County of Varaždin & $66.19 \%$ & $73.31 \%$ & $64.22 \%$ & $8.20 \%$ & 2573 & 9.57 \\
6 & County of Koprivnica-Križevci & $63.89 \%$ & $74.51 \%$ & $62.85 \%$ & $10.15 \%$ & 2604 & 8.77 \\
7 & County of Bjelovar-Bilogora & $63.04 \%$ & $75.44 \%$ & $63.86 \%$ & $10.91 \%$ & 2603 & 8.68 \\
& County of Primorje-Gorski & & & & & & \\
8 & kotar & $64.65 \%$ & $63.89 \%$ & $56.63 \%$ & $11.21 \%$ & 3697 & 10.56 \\
9 & County of Lika-Senj & $58.48 \%$ & $88.10 \%$ & $69.03 \%$ & $8.68 \%$ & 3033 & 8.51 \\
10 & County of Virovitica-Podravina & $62.45 \%$ & $70.59 \%$ & $58.09 \%$ & $13.96 \%$ & 2341 & 8.59 \\
11 & County of Požega-Slavonia & $61.26 \%$ & $65.36 \%$ & $53.52 \%$ & $13.90 \%$ & 2670 & 8.49 \\
& County of Slavonski Brod- & & & & & & \\
12 & Posavina & $60.96 \%$ & $56.91 \%$ & $46.45 \%$ & $15.73 \%$ & 2662 & 8.75 \\
13 & County of Zadar & $63.04 \%$ & $62.47 \%$ & $49.38 \%$ & $18.90 \%$ & 3426 & 9.77 \\
14 & County of Osijek-Baranja & $65.68 \%$ & $62.08 \%$ & $47.43 \%$ & $22.89 \%$ & 2958 & 9.57 \\
15 & County of Šibenik-Knin & $56.91 \%$ & $65.79 \%$ & $45.91 \%$ & $28.16 \%$ & 3262 & 9.01 \\
16 & County of Vukovar-Sirmium & $61.39 \%$ & $56.75 \%$ & $42.57 \%$ & $24.07 \%$ & 3106 & 8.67 \\
17 & County of Split-Dalmatia & $63.22 \%$ & $60.53 \%$ & $48.14 \%$ & $19.64 \%$ & 3617 & 10.17 \\
18 & County of Istria & $65.51 \%$ & $64.15 \%$ & $58.70 \%$ & $8.38 \%$ & 3330 & 9.91 \\
19 & County of Dubrovnik-Neretva & $62.67 \%$ & $65.34 \%$ & $53.88 \%$ & $17.42 \%$ & 3519 & 10.22 \\
20 & County of Međimurje & $65.95 \%$ & $67.60 \%$ & $58.98 \%$ & $12.27 \%$ & 2999 & 9.60 \\
22 & City of Zagreb & $66.38 \%$ & $64.06 \%$ & $57.08 \%$ & $10.71 \%$ & 3895 & 11.49 \\
\hline
\end{tabular}

There also exist heterogeneities within many counties (table 7). For example, the distribution of earnings for the individuals who are employed are the most unequal in the county of Lika-Senj and many counties in the Central Region and Eastern Region, where the average earnings level is low. However, the two counties in the Zagreb Region, where the average earnings level is the highest, have the most equal distribution. Graph 4 shows that, for example, in the County of Lika-Senj, the level of earnings of the individuals who are employed clusters at two separate low levels, which is the so-called twin-peak distribution in econometrics; however, in the County of Zagreb, the earnings concentrates at a relatively higher level. The large inequality in distribution of earnings might aggravate the difficult situation that poor people face in the County of Lika-Senj. 
Table 7 -- Inequality of earnings at the county level in Croatia (2002-04)

\begin{tabular}{clc}
\hline number & \multicolumn{1}{c}{ County } & Gini of earning \\
\hline 1 & County of Zagreb & 0.22 \\
18 & County of Istria & 0.23 \\
22 & City of Zagreb & 0.25 \\
2 & County of Krapina-Zagorje & 0.25 \\
8 & County of Primorje-Gorski kotar & 0.25 \\
17 & County of Split-Dalmatia & 0.26 \\
3 & County of Sisak-Moslavina & 0.26 \\
15 & County of Šibenik-Knin & 0.27 \\
19 & County of Dubrovnik-Neretva & 0.27 \\
4 & County of Karlovac & 0.29 \\
14 & County of Osijek-Baranja & 0.30 \\
16 & County of Vukovar-Sirmium & 0.30 \\
13 & County of Zadar & 0.30 \\
20 & County of Međimurje & 0.31 \\
11 & County of Požega-Slavonia & 0.35 \\
10 & County of Virovitica-Podravina & 0.36 \\
12 & County of Slavonski Brod-Posavina & 0.36 \\
7 & County of Bjelovar-Bilogora & 0.36 \\
5 & County of Varaždin & 0.38 \\
9 & County of Lika-Senj & 0.38 \\
6 & County of Koprivnica-Križevci & 0.38 \\
\hline
\end{tabular}

Note: The Gini coefficient of earnings is calculated for the individuals who are employed with positive earning.

\section{Graph 4 - The distribution of monthly earnings in the County of Zagreb and the County of Lika-Senj (2002-04)}

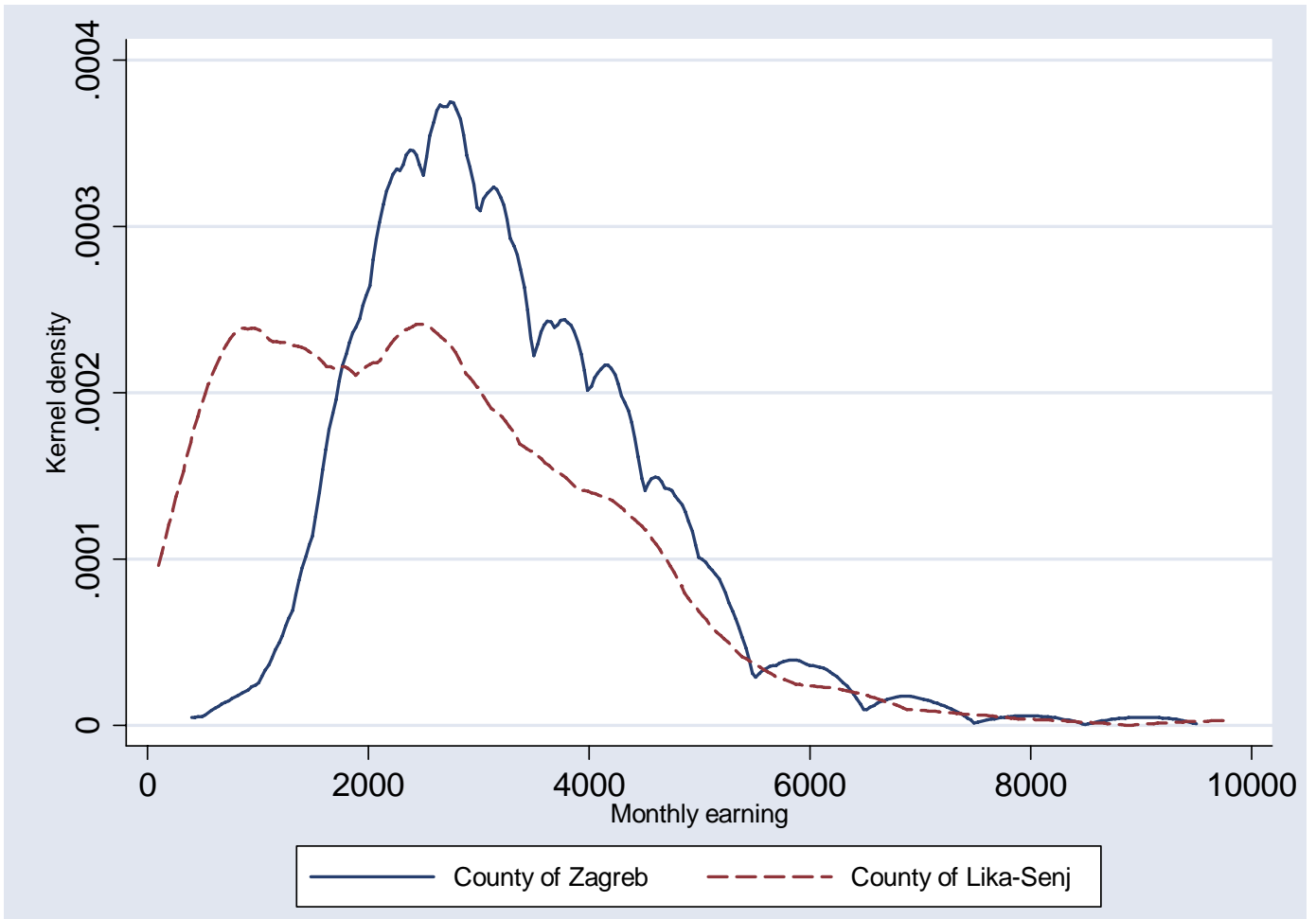




\section{Determination of employment and earnings}

The distribution of earnings largely varies across regions, age groups, education groups, and gender. Graph 5 shows that the distribution of the earnings in the Central Region and that in the Eastern Region are very similar; while the distribution of the other three regions clustered to a higher end. Graph 6 shows that for the individuals employed, the youth group has the lowest level of earning. Their situations are worse when the low youth employment rate is taken into consideration. Graph 7 shows that the level of earnings monotonically increases with the level of schooling in a significant way. Graph 8 shows that women have lower earnings than men.

In this section, we will study the determination of employment and earnings at the national and regional levels, decompose the roles of individual and regional structural characteristics in earnings differentials for the individuals employed, and try to examine their different roles between regions.

Graph 5: Distribution of earnings by region in Croatia (2002-2004)

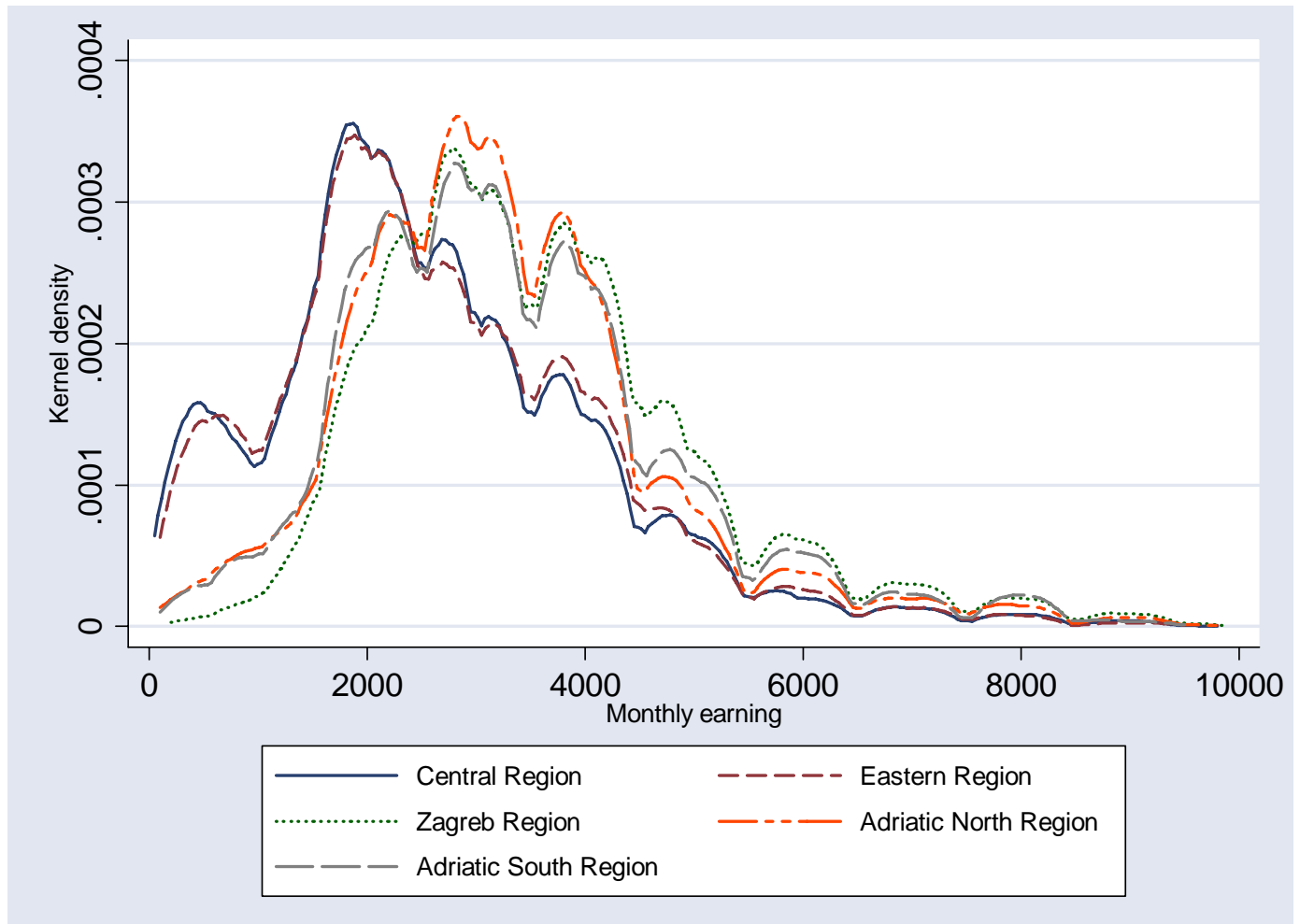


Graph 6: Distribution of earnings by age group in Croatia (2002-2004)

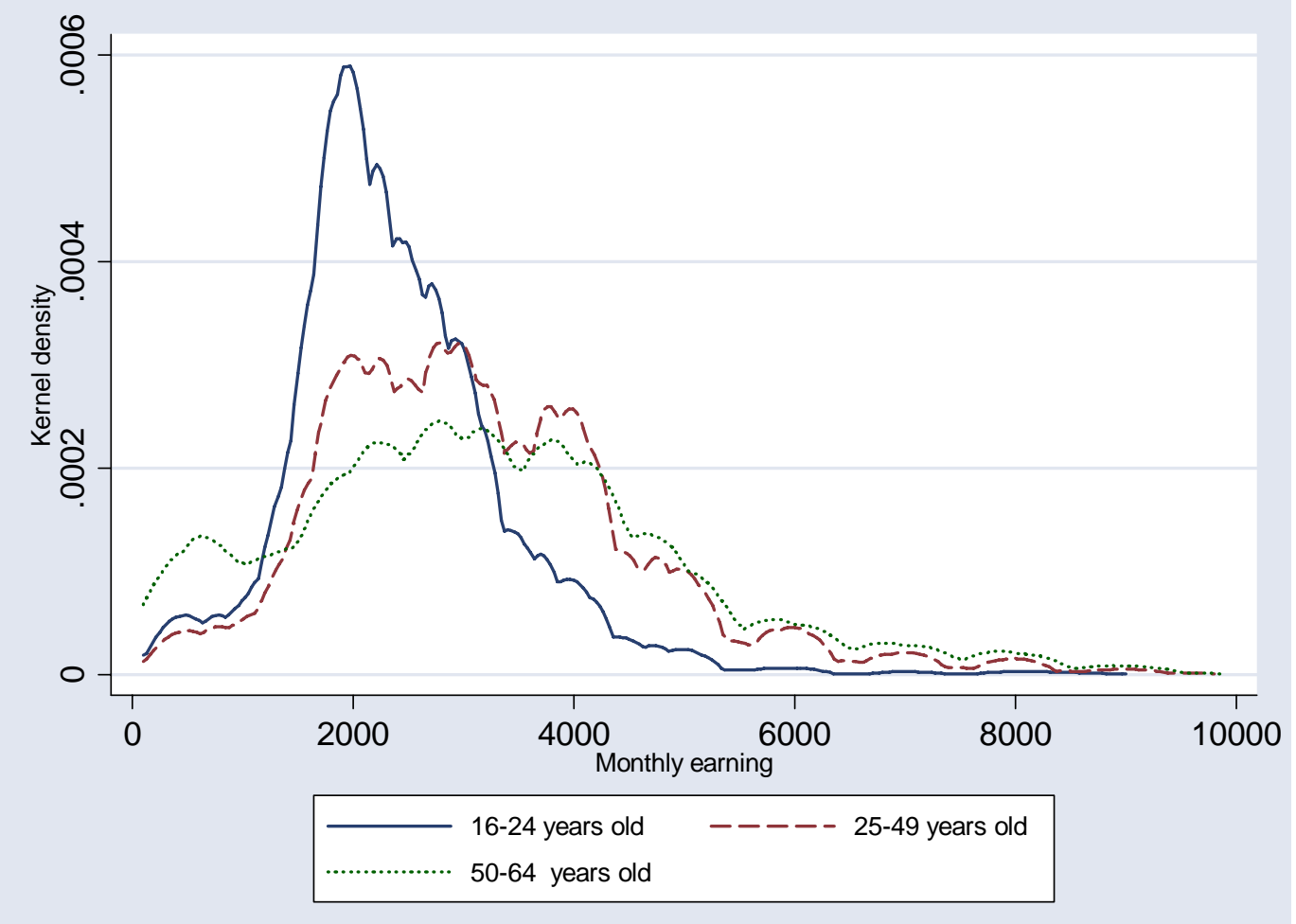

Graph 7: Distribution of earnings by education group in Croatia (2002-2004)

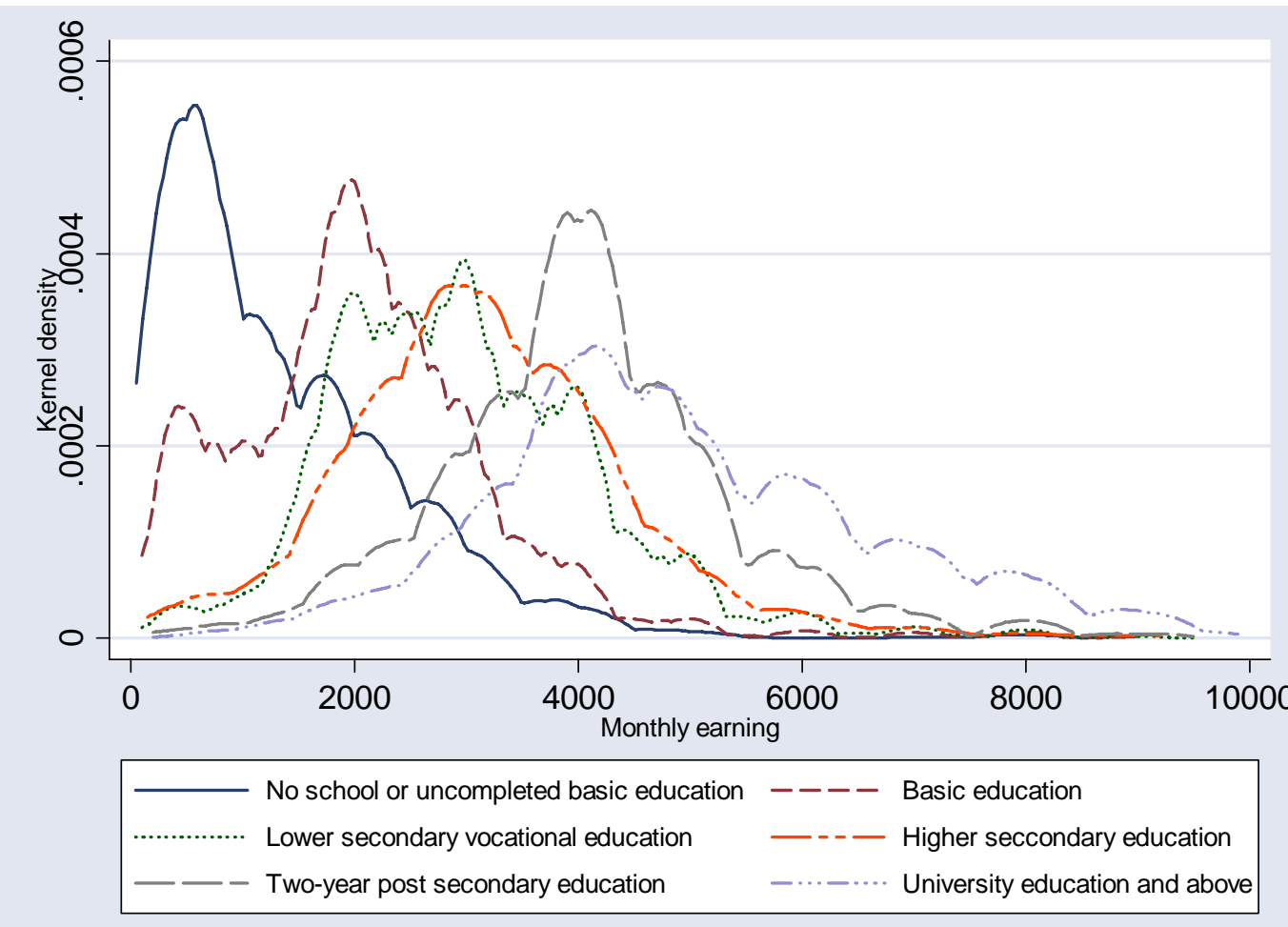


Graph 8: Distribution of earnings by gender in Croatia (2002-2004)

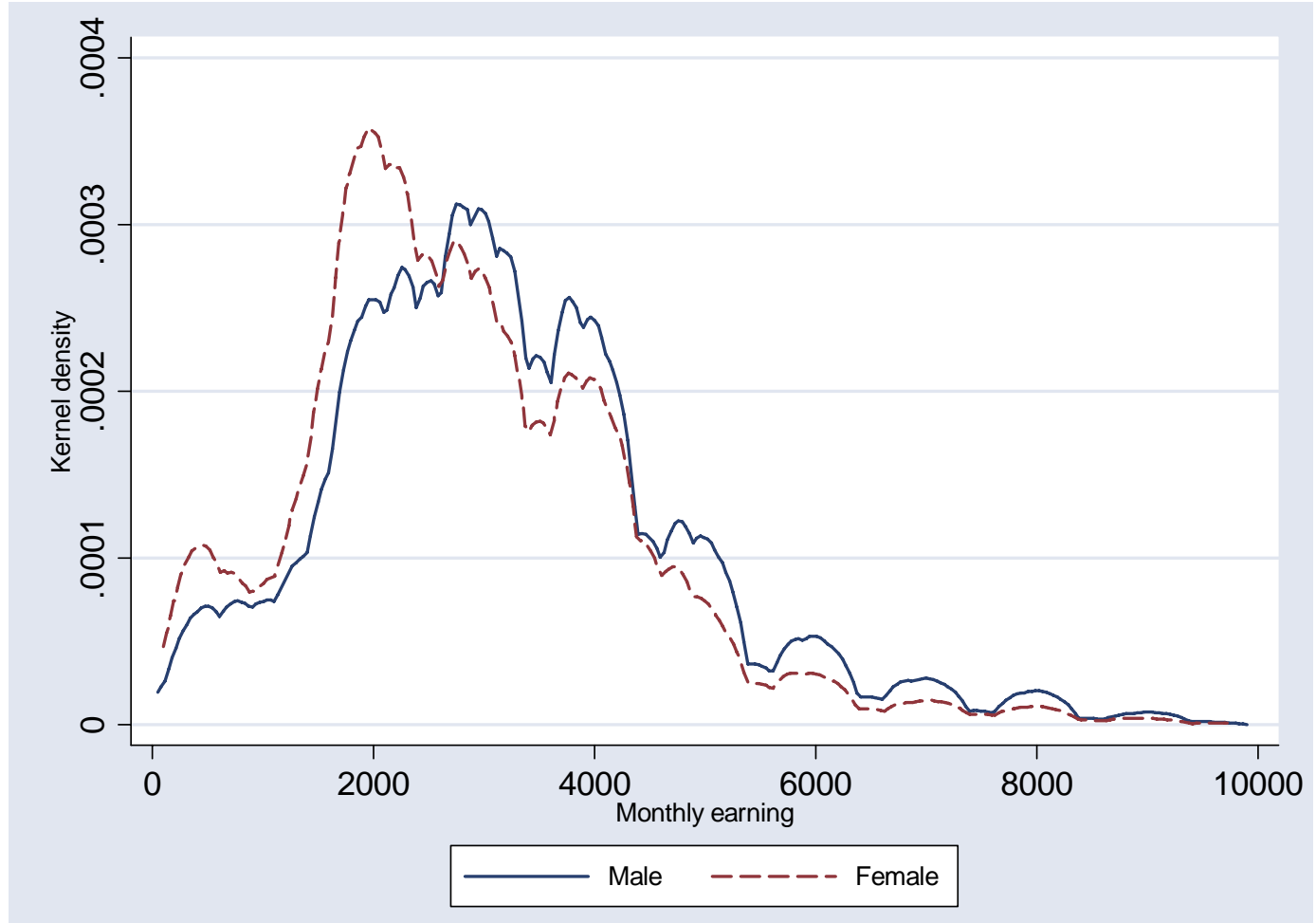

\subsection{Determination of employment and earnings at the national and regional levels}

An individual chooses whether to join the work force or whether he or she gets a job depends on whether his or her reservation wage is greater than the wage offered by the employers. The individuals who choose to work are different from those who choose not to work. In other words, a random participation-in-the-labor-force assumption is unlikely to be true. In the survey, we can only observe the earnings of the individuals who work for the individuals who would have wages lower than their reservation wages may be less likely to choose to work. ${ }^{16}$

The individual characteristics, captured by age, education, and gender, as well as the specific regional structural characteristics affect both the chances for the reservation wages and the offer wages; while some individual characteristics (in the jargon of economics, the identifying variables), such as marital status and being household head or not, which mainly affect an individual's incentives to work but not his or her competitiveness in job markets, may affect only the chances for the reservation wages (the chance of getting a job) but not the offer wages (the earnings if he or she gets a job).

\footnotetext{
${ }^{16}$ It does not necessarily imply that the individuals who do not choose to work would have a lower level of earnings should they choose to work. It can be the case that they could have even higher offer wages than those who actually choose to work - the former may have higher offer wages, but they choose not to work because they have even higher reservation wages. See Gronau (1974).
} 
Assuming that the monthly wage is a function of age, education, and gender, whereas the probability of employment (the likelihood of the wage being observed) is a function of marital status and whether the individual in question is a household head or not, and wage (via the inclusion of age, education, and gender, which we use to determine wage), we will use the Heckman estimation model instead of the Ordinary Least Square regressions to fit a wage model, for the sample of observed wages could be biased upward. ${ }^{17}$ To capture the non-linear effects of age on employment and earning, we introduce the variable "age square" into the equations. ${ }^{18}$ Based on the pooled LFS data 2002-2004 for the entire country, we estimate the equations as follows:

Income equation:

$$
\text { wage }=\beta_{0}+\beta_{1} \text { age }+\beta_{2} \text { age }{ }^{2}+\beta_{3} \text { education }+\beta_{4} \text { sex }+\sum \delta_{i} \text { regional_dummy } y_{i}+\mu_{1}
$$

Selection equation (wage is observed if):

$$
\begin{aligned}
& \gamma_{0}+\gamma_{1} \text { age }+\gamma_{2} \text { age }{ }^{2}+\gamma_{3} \text { education }+\gamma_{4} \text { sex }+\gamma_{5} \text { married }+\gamma_{6} \text { household_head } \\
& +\sum \theta_{i} \text { regional_dummy }{ }_{i}+\mu_{2}>0
\end{aligned}
$$

where $i=2,3,4,5$, considering Region 1 (Central Region) as reference; and $\operatorname{corr}\left(\mu_{1}, \mu_{2}\right)=\rho$.

The estimation of regression 1 in table 8 shows that, at the national level, age plays a significantly positive role in employment and earning, but the positive effects decrease as age increases; ${ }^{19}$ human capital, here measured by years of school, has positive effects on employment in a significant way, and the earnings level of an individual monotonically increases with his or her education endowment; women have a harder time to get a job than men, and face a lower level of earnings if they manage to get employed nonetheless, others being equal; being married or household head increases an individual's probability to be employed, partly because of his/her stronger incentives to seek employments. The estimations of regression 2 show that all regional dummies are significant. It suggests that the probability of employment and the level of earnings significantly differ across regions for individuals with similar characteristics in age, education, and gender. More specifically, on employment, in comparison with the Central Region (where the employment rate is the highest), individuals with similar individual characteristics have lower chance to get employed in the other four regions - among these four regions, the individuals have the lowest chance to get employed in Adriatic South Region, and the highest chance in Adriatic North Region. On earning, in comparison with the Central

\footnotetext{
${ }^{17}$ For further discussion on the methodology of the Heckman estimation, see Heckman $(1976 ; 1979)$ and Greene (2003).

${ }^{18}$ We had also tried to introduce the "years of school square" into the equations. However, the results show that effects of education on employment and earnings are not significantly non-linear.

${ }^{19}$ Based on the results of table 8 , the positive effects of age on employment reach the maximum level before those on earnings reach the maximum level. Instead of arguing the exact golden age for employment/earning, we would like to suggest that one's earnings level (if he or she is employed) may continue to increase for a certain period after his or her age has the maximum positive impacts on employment, because experience counts. The studies at the regional level show that, given the difference in job market structure and in labor supply, the magnitude of the effects of experience varies across regions.
} 
region (where the monthly earnings level is one of the lowest, similar as the Eastern Region), the individuals who are employed have much higher earnings in Zagreb Region, Adriatic North Region, and Adriatic South Region. Women have a lower probability to get a job than men in every region - they have the hardest condition in the Eastern Region and the most favorable condition in the Zagreb Region; for those who manage to get a job, women workers earn less than men, particularly in the Adriatic North Region and the Adriatic South Region.

Table 8 -- Determination of employment and earnings at the national level in Croatia (2002-2004) - using years of school as an indicator of human capital

\begin{tabular}{|c|c|c|c|c|}
\hline \multirow{3}{*}{$\begin{array}{l}\text { Estimat } \\
\text { kuna)) }\end{array}$} & \multicolumn{2}{|c|}{$\underline{\text { Regression } 1}$} & \multicolumn{2}{|c|}{$\underline{\underline{\text { Regression } 2}}$} \\
\hline & \multirow[b]{2}{*}{ Coef. } & \multirow[b]{2}{*}{ t-stat. } & \multirow[b]{2}{*}{ Coef. } & \multirow[b]{2}{*}{ t-stat. } \\
\hline & & & & \\
\hline age & 0.09 & 12.57 & 0.09 & 12.45 \\
\hline age*age & 0.00 & -9.32 & 0.00 & -9.24 \\
\hline years of school & 0.34 & 103.1 & 0.32 & 94.17 \\
\hline $\operatorname{sex}($ male $=0$, female $=1)$ & -0.64 & -34.94 & -0.67 & -36.66 \\
\hline \multicolumn{5}{|c|}{ Regional dummies (Central Region as reference) } \\
\hline Eastern Region & & & 0.06 & 2.44 \\
\hline Zagreb Region & & & 0.68 & 27.25 \\
\hline Adriatic North Region & & & 0.60 & 20.41 \\
\hline Adriatic South Region & & & 0.50 & 18.29 \\
\hline constant & -2.68 & -16.1 & -2.69 & -16.45 \\
\hline \multicolumn{5}{|c|}{ Estimation of selection equations } \\
\hline & Coef. & t-stat. & Coef. & t-stat. \\
\hline age & 0.23 & 85.78 & 0.23 & 85.48 \\
\hline age*age & 0.00 & -91.1 & 0.00 & -90.73 \\
\hline years of school & 0.05 & 28.14 & 0.05 & 29.83 \\
\hline $\operatorname{sex}($ male $=0$, female $=1)$ & -0.24 & -21.44 & -0.23 & -21.26 \\
\hline \multicolumn{5}{|c|}{ Regional dummies (Central Region as reference) } \\
\hline Eastern Region & & & -0.21 & -15.03 \\
\hline Zagreb Region & & & -0.20 & -14.53 \\
\hline Adriatic North Region & & & -0.10 & -5.81 \\
\hline Adriatic South Region & & & -0.30 & -20.35 \\
\hline married & 0.21 & 17.38 & 0.21 & 17.3 \\
\hline household head & 0.20 & 15.54 & 0.20 & 15.45 \\
\hline constant & -4.58 & -91.26 & -4.47 & -88.11 \\
\hline Log likelihood & -121325 & & -120545 & \\
\hline Number of observations & 78148 & & 78148 & \\
\hline
\end{tabular}

Note: All coefficients are significant in $1 \%$.

Given the large variation of the labor market structure and performance in different regions, we relax the implicit assumption on the homogeneities of the roles of the individual characteristics in employment and earnings across regions, and estimate the 
Heckman selection and income equations separately. The results of table 9 show that, in each region, the variables of age, education, gender, marital status, and household head, have their significant expected signs. However, their marginal effects on employment and earnings differ. In each region, the positive effects of age on employment reach the maximum level when age is about 40, while those on earnings vary. It suggests that the rewards to experience differ across regions depending on the supply and demand in the job market. The return of education also differs to a large extent across regions. Among the five regions, the return of an additional year of school on employment is the highest in the Eastern Region and the lowest in the Central Region. However, for the individuals who are employed, their return of education for each additional year of school on earnings is the highest in the Zagreb Region, closely followed by the Central Region, and the lowest in the Eastern Region, others being equal (table 10). 
Table 9: Determination of employment and earnings at the regional levels - using years of school as an indicator of human capital

\begin{tabular}{|c|c|c|c|c|c|c|c|c|c|c|}
\hline & \multicolumn{2}{|c|}{ Central Region } & \multicolumn{2}{|c|}{ Eastern Region } & \multicolumn{2}{|c|}{ Zagreb Region } & \multicolumn{2}{|c|}{ Adriatic West Region } & \multicolumn{2}{|c|}{ Adriatic South Region } \\
\hline & Coefficient & t-statistics & Coefficient & t-statistics & Coefficient & t-statistics & Coefficient & t-statistics & Coefficient & t-statistics \\
\hline \multicolumn{11}{|c|}{ Estimation of income equations (dependant variable: monthly earnings (in thousand kuna)) } \\
\hline age & 0.124 & 9.73 & 0.094 & 6.62 & 0.060 & 3.4 & 0.122 & 4.56 & 0.044 & 2.18 \\
\hline age*age & -0.001 & -8.46 & -0.001 & -4.98 & 0.000 & -1.63 & -0.001 & -3.6 & 0.000 & -0.93 \\
\hline years of school & 0.333 & 56.61 & 0.283 & 40.01 & 0.344 & 49.38 & 0.302 & 27.15 & 0.300 & 30.71 \\
\hline $\begin{array}{l}\text { sex }(\text { male }=0, \\
\text { female }=1)\end{array}$ & -0.628 & -19.26 & -0.571 & -14 & -0.525 & -15.17 & -0.900 & -15.95 & -0.810 & -16.18 \\
\hline constant & -3.287 & -11.79 & -2.252 & -6.9 & -1.944 & -5.01 & -2.418 & -4.06 & -1.018 & -2.2 \\
\hline \multicolumn{11}{|c|}{ Estimation of selection equations } \\
\hline age & 0.198 & 39.2 & 0.198 & 34.33 & 0.280 & 46.89 & 0.263 & 33.27 & 0.230 & 35.93 \\
\hline age*age & -0.003 & -41.25 & -0.002 & -35.68 & -0.004 & -50.54 & -0.003 & -35.65 & -0.003 & -37.89 \\
\hline years of school & 0.022 & 6.33 & 0.079 & 21.13 & 0.058 & 15.51 & 0.047 & 8.9 & 0.072 & 16.61 \\
\hline $\begin{array}{l}\text { sex }(\text { male }=0, \\
\text { female }=1)\end{array}$ & -0.218 & -9.93 & -0.412 & -16.16 & -0.148 & -6.69 & -0.215 & -6.9 & -0.196 & -7.24 \\
\hline married & 0.235 & 9.97 & 0.241 & 8.97 & 0.239 & 9.26 & 0.134 & 3.73 & 0.186 & 6.28 \\
\hline household head & 0.104 & 4.01 & 0.198 & 6.79 & 0.183 & 7.27 & 0.188 & 5.3 & 0.317 & 9.99 \\
\hline constant & -3.655 & -38.27 & -4.464 & -41.36 & -5.563 & -49.4 & -5.040 & -33.31 & -5.094 & -41.38 \\
\hline Log likelihood & -31949.15 & & -23680.53 & & -27311.09 & & -15275.03 & & -21660.24 & \\
\hline $\begin{array}{l}\text { Number of } \\
\text { observations }\end{array}$ & 19519 & & 16479 & & 18379 & & 9355 & & 14416 & \\
\hline
\end{tabular}


Table 10 Rankings of impacts of years of school on earnings and on employment across regions

\begin{tabular}{cccc}
\hline \hline Region & Impacts on earning & Region & Impacts on employment \\
\hline Eastern Region & 0.283 & Central Region & 0.022 \\
Adriatic South Region & 0.300 & Adriatic North Region & 0.047 \\
Adriatic North Region & 0.302 & Zagreb Region & 0.058 \\
Central Region & 0.333 & Adriatic South Region & 0.072 \\
Zagreb Region & 0.344 & Eastern Region & 0.079 \\
\hline \hline
\end{tabular}

The difference in the impacts of education on employment and on earnings at the regional level may be explained by the difference in the distribution of human capital and the difference in employment structure. For example, the employment rate in Central Region is high. The large share of the low-paid manufacturing job may lower the comparative attractiveness of the better educated individuals in the labor market when they seek employment; while for those who do manage to secure a job, they may have a relatively high earnings given the scarcity of the human capital (as the statistics show, the average years of school in Central Region is relatively low compared with the national average). In Eastern Region, the large impact of years of school on employment may reflect the low-demand from the job market, which corresponds to the low employment rate there. Only those relatively well educated have a better chance to get a job; while the tight competition for a job on the supply side lowers the market clearing level of earnings for those who are employed. In the Adriatic South Region, where employment rate is relatively low and a large part of jobs are seasonal, the individuals with better education may have a better chance to find a job.

Trying to study the effects of different levels of education in addition to those of "years of school", we use the "level of schooling" as the indicator of human capital to reexamine the determination of employment and earnings (table 11 and table 12). ${ }^{20}$ The results using "level of schooling" offer support to those using "years of school" as the indicator of human capital. At the national level, the selection equations indicate that the individuals with vocational secondary education, two-year post secondary education, and university education and above have significantly higher chance to get a job. Individuals with basic education do not have better chance to get employed compared with those with no education or uncompleted basic education. ${ }^{21}$ It seems to suggest that, in the Croatian economy, there is a certain threshold for the level of schooling to be effective, which is likely to be secondary education, below which the return is low. The income equations

\footnotetext{
${ }^{20}$ In the analysis, we have six levels of education, including "no school or uncompleted basic education", "basic education", "lower secondary vocational education", "higher secondary education (grammar school)", "two-year post secondary education", and "university education and above". To compare the effects of levels of education on employment and earning, we use "no school or uncompleted basic education" as the reference.

${ }^{21}$ The results show that the individuals with grammar school as their highest level of schooling do not have advantage in getting a job compared with the others. We will not examine this in details because of the following two reasons: 1 . very few individuals belong to this category; 2 . the individuals who belong to this category have low participation rates.
} 
suggest that each additional level of schooling has significantly positive impacts on earnings in all regions. For the individuals who are employed, others being equal, those with secondary education have higher earnings than those with basic education or less; and those with tertiary education (in particular university and above) have even higher earnings than those with secondary education.

\section{Table 11 -- Determination of employment and earnings at the national level in Croatia (2002-2004) -- using level of schooling as indicator of human capital}

\begin{tabular}{|c|c|c|c|c|}
\hline \multicolumn{5}{|c|}{$\begin{array}{lll}\text { Regression } 3 & \underline{\text { Regression } 4}\end{array}$} \\
\hline \multicolumn{5}{|c|}{ Estimation of income equations (dependant variable: monthly earnings (in thousand kuna)) } \\
\hline & Coef. & t-statistics & Coef. & t-statistics \\
\hline age & 0.113 & 15.71 & 0.109 & 15.48 \\
\hline age*age & -0.001 & -13.24 & -0.001 & -13.08 \\
\hline \multicolumn{5}{|c|}{ Level of schooling ("No school or uncompleted basic education" as reference) } \\
\hline Basic education & 0.649 & 12.96 & 0.571 & 11.57 \\
\hline Lower secondary vocational education & 1.645 & 34.07 & 1.441 & 30.03 \\
\hline Higher secondary education & 1.986 & 29.43 & 1.726 & 25.83 \\
\hline Two-year post secondary education & 2.815 & 49.13 & 2.577 & 45.24 \\
\hline University education and above & 3.781 & 69.98 & 3.494 & 64.72 \\
\hline $\operatorname{sex}($ male $=0$, female $=1)$ & -0.660 & -36.11 & -0.688 & -38.25 \\
\hline \multicolumn{5}{|c|}{ Regional dummies (Central Region as reference) } \\
\hline Eastern Region & & & 0.065 & 2.56 \\
\hline Zagreb Region & & & 0.729 & 29.46 \\
\hline Adriatic North Region & & & 0.634 & 21.62 \\
\hline Adriatic South Region & & & 0.538 & 19.74 \\
\hline constant & -0.661 & -4.25 & -0.743 & -4.89 \\
\hline \multicolumn{5}{|l|}{ Estimation of selection equations } \\
\hline & Coef. & t-statistics & Coef. & t-statistics \\
\hline age & 0.220 & 81.64 & 0.220 & 81.28 \\
\hline age*age & -0.003 & -87.7 & -0.003 & -87.31 \\
\hline \multicolumn{5}{|c|}{ Level of schooling ("No school or Uncompleted basic education" as reference) } \\
\hline Basic education & -0.041 & -1.8 & -0.034 & -1.48 \\
\hline Lower secondary vocational education & 0.278 & 12.69 & 0.307 & 13.86 \\
\hline Higher secondary education & -0.183 & -6.02 & -0.141 & -4.59 \\
\hline Two-year post secondary education & 0.564 & 19.11 & 0.606 & 20.35 \\
\hline University education and above & 0.615 & 22.74 & 0.662 & 24.08 \\
\hline $\operatorname{sex}($ male $=0$, female $=1)$ & -0.213 & -19.15 & -0.212 & -18.96 \\
\hline \multicolumn{5}{|c|}{ Regional dummies (Central Region as reference) } \\
\hline Eastern Region & & & -0.213 & -14.92 \\
\hline Zagreb Region & & & -0.205 & -14.5 \\
\hline Adriatic North Region & & & -0.109 & -6.38 \\
\hline Adriatic South Region & & & -0.316 & -21.11 \\
\hline married & 0.201 & 16.44 & 0.201 & 16.39 \\
\hline household head & 0.197 & 15.46 & 0.197 & 15.35 \\
\hline constant & -4.062 & -78.35 & -3.927 & -74.79 \\
\hline Log likelihood & -120705 & & -119837 & \\
\hline Number of observations & 78148 & & 78148 & \\
\hline
\end{tabular}

Note: All coefficients are significant in 1\%, except the dummy "basic education", which is not significant at $5 \%$ in the selection equations. 
At the regional level, the positive effects of having tertiary education (including two-year post secondary education and university education and above) are the largest in the Eastern Region and the Zagreb Region, and the lowest in the Central Region. We tend to argue that, the reasons why the return on tertiary education is high in the Eastern Region and Zagreb Region are different - in Eastern region, the employment rate is low (the unemployment rate is high), only the most qualified has a higher chance to get a job; while in Zagreb, the high demand for jobs that require high skills (for example, the jobs in financial sector) favor the individuals with better education. The individuals with loweducation may face difficulties in finding a job because of the mismatch of skills. In Central Region, to the contrary, the high demand for jobs that require lower skill (for example, the low-paid jobs in manufacturing sector) favors the individuals with less education, who may have lower reservation wage. The return on education, in particular on tertiary education, is the highest for those who are employed in Central Region, followed by Zagreb Region. 
Table 12: Determination of employment and earnings at the regional and national levels using level of schooling as indicator of human capital

\begin{tabular}{|c|c|c|c|c|c|c|c|c|c|c|}
\hline & \multicolumn{2}{|c|}{ Central Region } & \multicolumn{2}{|c|}{ Eastern Region } & \multicolumn{2}{|c|}{ Zagreb Region } & \multicolumn{2}{|c|}{ Adriatic North Region } & \multicolumn{2}{|c|}{ Adriatic South Region } \\
\hline & Coefficient & t-statistics & Coefficient & t-statistics & Coefficient & t-statistics & Coefficient & t-statistics & Coefficient & t-statistics \\
\hline \multicolumn{11}{|c|}{ Estimation of income equations (dependant variable: monthly earnings (in thousand kuna)) } \\
\hline age & 0.144 & 11.9 & 0.119 & 8.87 & 0.070 & 4.24 & 0.130 & 5.47 & 0.051 & 2.64 \\
\hline age*age & -0.002 & -11.23 & -0.001 & -7.81 & -0.001 & -2.68 & -0.001 & -4.58 & 0.000 & -1.69 \\
\hline Basic education & 0.486 & 6.98 & 0.405 & 4.59 & 0.612 & 3.61 & 0.374 & 1.75 & 0.711 & 4.31 \\
\hline education & 1.456 & 21.34 & 1.231 & 14.26 & 1.325 & 7.94 & 1.278 & 6.12 & 1.420 & 9.07 \\
\hline Higher secondary education & 1.845 & 14.15 & 1.434 & 11.06 & 1.768 & 9.79 & 1.293 & 5.07 & 1.531 & 7.83 \\
\hline Two-year post secondary education & 2.667 & 28.48 & 2.560 & 22.81 & 2.339 & 13.22 & 2.241 & 9.82 & 2.568 & 15 \\
\hline University education and above & 3.995 & 44.48 & 3.104 & 29.39 & 3.473 & 20.26 & 3.073 & 13.85 & 3.202 & 18.99 \\
\hline $\operatorname{sex}($ male $=0$, female $=1)$ & -0.651 & -20.12 & -0.589 & -14.81 & -0.563 & -16.45 & -0.909 & -16.38 & -0.825 & -16.53 \\
\hline constant & -1.235 & -4.8 & -0.597 & -2.03 & 0.536 & 1.37 & -0.305 & -0.56 & 0.953 & 2.19 \\
\hline \multicolumn{11}{|l|}{ Estimation of selection equations } \\
\hline age & 0.193 & 37.89 & 0.194 & 33.38 & 0.265 & 43.55 & 0.252 & 31.37 & 0.219 & 33.68 \\
\hline age*age & -0.002 & -40.2 & -0.002 & -35.5 & -0.003 & -47.38 & -0.003 & -33.9 & -0.003 & -36.01 \\
\hline Basic education & -0.082 & -2.18 & -0.056 & -1.27 & 0.309 & 4.31 & 0.199 & 2.36 & -0.019 & -0.31 \\
\hline $\begin{array}{l}\text { Lower secondary vocational } \\
\text { education }\end{array}$ & 0.089 & 2.39 & 0.367 & 8.54 & 0.805 & 11.72 & 0.523 & 6.45 & 0.351 & 5.99 \\
\hline Higher secondary education & -0.489 & -7.71 & 0.069 & 1.05 & 0.253 & 3.26 & -0.035 & -0.34 & 0.074 & 0.98 \\
\hline Two-year post secondary education & 0.356 & 6.08 & 0.874 & 12.81 & 0.969 & 12.33 & 0.713 & 7.36 & 0.736 & 10.51 \\
\hline University education and above & 0.374 & 6.57 & 1.101 & 16.75 & 1.013 & 13.94 & 0.710 & 7.72 & 0.831 & 12.2 \\
\hline sex $($ male $=0$, female $=1)$ & -0.198 & -8.93 & -0.400 & -15.53 & -0.106 & -4.7 & -0.178 & -5.64 & -0.181 & -6.63 \\
\hline married & 0.228 & 9.57 & 0.247 & 9.15 & 0.202 & 7.75 & 0.123 & 3.4 & 0.185 & 6.2 \\
\hline household head & 0.105 & 4.01 & 0.205 & 7.01 & 0.176 & 6.94 & 0.186 & 5.22 & 0.322 & 10.13 \\
\hline constant & -3.342 & -34.99 & -3.751 & -34.1 & -5.289 & -41.49 & -4.728 & -28.66 & -4.353 & -34.03 \\
\hline
\end{tabular}

Note: "No school or uncompleted basic education" as reference. 


\subsection{Role of individual and regional structural characteristics in wage differentials}

If the labor market structures are similar across regions, individuals with similar characteristics will have similar employment and earnings no matter where he or she lives. ${ }^{22}$ However, in Croatia, employment and wages differ across regions even after one has accounted for all these personal characteristics. ${ }^{23}$ In this section, we will study the relative importance of the role of individual characteristics and regional structural characteristics in wage differential between regions by using the Oaxaca decomposition methods (Oaxaca, 1973; Oaxaca and Ransom, 1994). We apply the wage structure of the reference region to simulate the earnings level of the region in question, and decompose the effects on regional wage differential. ${ }^{24}$

The results of table 13 show that, taking the wage structure of the Central Region as reference, individual characteristics, measured by age, education, and gender, account for about two-thirds of the wage difference between the Eastern Region and the Central Region, and the other characteristics account for the rest one-third; however, individual characteristics account for roughly one-third of the wage difference between the Zagreb Region and the Central Region, between the Adriatic North Region and the Central Region, and between the Adriatic South Region and the Central Region; while the other characteristics accounts for two-thirds. ${ }^{25}$ It suggests the relative similarity of wage structure between the Central Region and Eastern Region and the large difference in wage structure between the other pairs of regions, which corresponds to the statistics on the regional difference in the labor market structure and performance.

\footnotetext{
${ }^{22}$ In this study, we focus on the employment and earnings differentials at the regional / county level, and leave the interesting discussions on the rural-urban divide for future work.

${ }^{23}$ In economic terms, regional discrimination in earnings can be said to exist whenever the relative earnings of one region exceeds the relative wage that would have prevailed if workers in two regions were paid according to the same criteria based on their individual characteristics. Here, we consider age, education, and gender as the major indicators of individual characteristics, and have to neglect other characteristics, such as entrepreneurship, due to information constraints. In other words, we may underestimate the effects of individual characteristics on wage differentials, and overestimate those of the regional structural characteristics because the inclusion of the effects of the unobservable individual characteristics into the regional ones

${ }^{24}$ See Oaxaca (1973) for the discussion on the methodologies of the decomposition of the effects of individual characteristics and regional characteristics on wage differentials.

${ }^{25}$ The relative importance of the role of individual and regional structural characteristics in wage differential between each pairs of regions is stable even if we change the reference region. In other words, the individual characteristics play a larger role than regional structural characteristics in the wage differential between the Central Region and the Eastern Region; while the regional structural characteristics play a larger role than individual characteristics in the wage differential between the other pairs of regions. Results are available upon request.
} 
Table 13: Decomposition of the effects of individual and other characteristics on regional earnings differentials

\begin{tabular}{lccc}
\hline \hline & $\begin{array}{c}\text { Effects of individual } \\
\text { characteristics (age, } \\
\text { education, and gender) on } \\
\text { mean earnings differential } \\
\text { between the region in } \\
\text { question and Central } \\
\text { Region }\end{array}$ & $\begin{array}{c}\text { Effects of other } \\
\text { characteristics on mean } \\
\text { earnings differential } \\
\text { between the region in } \\
\text { question and Central } \\
\text { Region }\end{array}$ \\
\hline Central Region & 2806 & $\ldots$ & $\ldots$ \\
Eastern Region & 2826 & $63.99 \%$ & $36.01 \%$ \\
Zagreb Region & 3735 & $34.55 \%$ & $65.45 \%$ \\
Adriatic North Region & 3498 & $28.45 \%$ & $71.55 \%$ \\
Adriatic South Region & 3524 & $30.70 \%$ & $69.30 \%$ \\
\hline \hline
\end{tabular}

\section{Effects of nation-wide education policy and regional-specific labor market policy}

An individual may earn more if he or she has better education, or if he or she moves to another region where the labor market better rewards his or her talents, others being equal. In this section, we will simulate the hypothetic effects of the nation-wide education policies and the regional-specific labor market policies on regional wage differentials.

\subsection{Effects of nation-wide education policy}

The estimations in the previous sections show that education plays a positive role in employment and earning, and the return on education varies across regions. If each working-age individual who is employed has one more year of school, what would be the employment rate and earnings level in each region?

Based on the selection estimations and the income estimations at the regional level, we will simulate the effects of such hypothetic one-additional-year-of-school national-wide education policy on regional labor market. The simulations include two steps: 1. For employment, taking age, age square, years of school, gender, marital status, and household head as determinants, we estimate the determination of employment in each region; then assuming each working-age individual has an additional year of school and applying the coefficients estimated, we simulate the effects of this nation-wide policy on employment. 2. For earning, taking age, age square, years of school, and gender as determinants, we estimate the determination of earnings for the individuals who are employed in each region; then assuming each working-age individual has an additional year of school and applying the coefficients estimated, we simulate the effects of this nation-wide policy on earning. 
The simulation results of table 14 show that, if the working-age population has one more year of education, the employment rate will increase $2.5-5.5 \%$ and the earnings level will increase $8-10.5 \%$ in five regions. The positive effects on employment are the largest in the Eastern Region, which suggests that for the given wage structure in this lagging region, the shortage of skilled labor (measured by years of school) is an important constraint. Although such education policy has large effects on earnings for those who are employed in the Central Region, its effects on employment may be limited. It may suggest that a general increase in human capital endowment at this stage may not much increase the job demand in Central region, but it may, to a large extent, enhance the labor productivity of those who are employed, which leads to the increase in wage. If we consider the product of the increase in employment and the increase in earnings as a rough measure of the total effects of the education policy, such nation-wide one-year-of-school-increase policy will have larger effects in the Eastern Region than elsewhere, which may contribute to balance the regional development. In addition, if being unemployed (rather than having low salary) is one of the major reasons for being poor, the large effects on employment in the Eastern Region could be further pro-poor.

Table 14 : Simulations of the effects on employment and earnings of nation-wide education policy by region

\begin{tabular}{|c|c|c|c|}
\hline & $\begin{array}{c}\text { Estimated } \\
\text { employment rate }\end{array}$ & $\begin{array}{c}\text { Simulated } \\
\text { employment rate }\end{array}$ & $\begin{array}{c}\% \text { increase in } \\
\text { employment rate due to } \\
\text { an additional year of } \\
\text { school }\end{array}$ \\
\hline Central Region & $60.89 \%$ & $62.48 \%$ & 2.54 \\
\hline Eastern Region & $47.74 \%$ & $50.50 \%$ & 5.47 \\
\hline Zagreb Region & $55.67 \%$ & $58.42 \%$ & 4.71 \\
\hline Adriatic North Region & $58.39 \%$ & $60.51 \%$ & 3.50 \\
\hline \multirow[t]{2}{*}{ Adriatic South Region } & $48.81 \%$ & $51.45 \%$ & 5.13 \\
\hline & $\begin{array}{l}\text { Estimated mean } \\
\text { monthly earning }\end{array}$ & $\begin{array}{l}\text { Simulated mean } \\
\text { monthly earning }\end{array}$ & $\begin{array}{l}\% \text { increase in earnings } \\
\text { due to an additional year } \\
\text { of school }\end{array}$ \\
\hline Central Region & 2785 & 3111 & 10.47 \\
\hline Eastern Region & 2811 & 3100 & 9.32 \\
\hline Zagreb Region & 3703 & 4046 & 8.48 \\
\hline Adriatic North Region & 3495 & 3795 & 7.91 \\
\hline Adriatic South Region & 3524 & 3827 & 7.90 \\
\hline
\end{tabular}

\subsection{Effects of regional specific labor market policy}

The estimation results in section 2 show that, after controlling for the individual characteristics, including age, education, and gender, the employment and earnings level still differ to a large extent across regions. If the working-age individuals who 
are employed in one region face the wage structure of another region, others being equal, what would be the employment rate and earnings level?

Using the similar methodologies as those for the simulation of the nation-wide education policy, we will study the effects of such hypothetical regional specific policy on employment and earnings, assuming the labor market structure in one region could be duplicated in another. ${ }^{26}$ Similarly, the simulations include two steps: 1. For employment, taking age, age square, years of school, gender, marital status, and household head as determinants, we estimate the determination of employment in each region; then assuming the labor market structure of the region in question is adjusted to the one of the reference region and applying the coefficients estimated for that reference region, we simulate the effects on employment in the region in question. 2. For earnings, taking age, age square, years of school, and gender as determinants, we estimate the determination of earnings for the individuals who are employed in each region; then assuming the labor market structure of the region in question is adjusted to the one of the reference region and applying the coefficients estimated for that reference region, we simulate the effects on earnings for those who are employed.

The results of table 15 show that, measured by employment, the labor market is the most dynamic in the Central Region, followed by the Adriatic North Region, and is the least dynamic in the Adriatic South Region and the Eastern Region. Measured by earning, the individuals employed are the least well rewarded by the wage structures in the Central Region and the Eastern Region, and are the best rewarded in the Zagreb Region, closely followed by the Adriatic North Region and the Adriatic South Region. Taking both employment and earnings into consideration, the labor market structure in Eastern Region is the least satisfactory one. We tend to argue that the low human capital endowment and the unsatisfactory labor market structure both lead to its backwardness in development. The dynamic labor market structure in the Adriatic North Region might be one of the important factors that contribute to its prosperity. The adjustment of the labor market structure of the Eastern Region towards those of the other regions may help to improve the dynamism of its labor market. Some measures that lower the barriers of labor mobility across regions may also help the individuals who migrate to get jobs that better reward their talents, and hence increase the nation-wide aggregate welfare level.

\footnotetext{
${ }^{26}$ The feasibility of the duplication of the wage structure of one region might be subject to further discussion. One objective here is to study the role of regional specific characteristics in employment and earnings determination. We hope that the results can, to some extent, shed light on the potential effects of inter-regional migration - even if the entire labor market structure of one region will not duplicate that of the other, what if some individuals move to another region?
} 
Table 15 : Simulations of the effects on employment and earnings of regional specific labor market policies by region

\begin{tabular}{|c|c|c|c|c|c|c|}
\hline \multirow[b]{2}{*}{$\begin{array}{l}\text { Central Region } \\
\text { Eastern Region } \\
\text { Zagreb Region } \\
\text { Adriatic North Region } \\
\text { Adriatic South Region }\end{array}$} & \multirow[b]{2}{*}{$\begin{array}{c}\text { Estimated } \\
\text { employment rate } \\
60.89 \% \\
47.74 \% \\
55.67 \% \\
58.39 \% \\
48.81 \% \\
\end{array}$} & \multirow[b]{2}{*}{$\begin{array}{c}\text { Estimated monthly } \\
\text { earning } \\
2785 \\
2811 \\
3703 \\
3495 \\
3524 \\
\end{array}$} & \multicolumn{4}{|c|}{ The labor market structure of Central Region as reference } \\
\hline & & & $\begin{array}{c}\text { simulated employment } \\
\text { rate } \\
60.89 \% \\
59.95 \% \\
62.07 \% \\
61.63 \% \\
61.58 \% \\
\end{array}$ & $\begin{array}{c}\text { \% change in } \\
\text { employment rate } \\
0.00 \\
20.36 \\
10.31 \\
5.27 \\
20.75 \\
\end{array}$ & $\begin{array}{c}\text { simulated monthly } \\
\text { earning } \\
2785 \\
2903 \\
3227 \\
3076 \\
3180 \\
\end{array}$ & 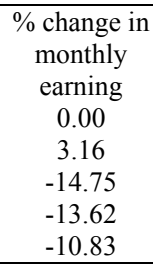 \\
\hline $\begin{array}{l}\text { Central Region } \\
\text { Eastern Region } \\
\text { Zagreb Region } \\
\text { Adriatic North Region } \\
\text { Adriatic South Region }\end{array}$ & $\begin{array}{c}\text { Estimated } \\
\text { employment rate } \\
60.89 \% \\
47.74 \% \\
55.67 \% \\
58.39 \% \\
48.81 \% \\
\end{array}$ & $\begin{array}{c}\text { Estimated monthly } \\
\text { earning } \\
2785 \\
2811 \\
3703 \\
3495 \\
3524 \\
\end{array}$ & $\begin{array}{c}\text { simulated employment } \\
\text { rate } \\
48.57 \% \\
47.74 \% \\
51.43 \% \\
50.56 \% \\
50.37 \% \\
\end{array}$ & $\begin{array}{c}\text { \% change in } \\
\text { employment rate } \\
-25.37 \\
0.00 \\
-8.23 \\
-15.47 \\
3.11 \\
\end{array}$ & $\begin{array}{c}\text { simulated monthly } \\
\text { earning } \\
2701 \\
2811 \\
3088 \\
2959 \\
3056 \\
\end{array}$ & $\begin{array}{c}\text { \% change in } \\
\text { monthly } \\
\text { earning } \\
-3.12 \\
0.00 \\
-19.91 \\
-18.09 \\
-15.34 \\
\end{array}$ \\
\hline $\begin{array}{l}\text { Central Region } \\
\text { Eastern Region } \\
\text { Zagreb Region } \\
\text { Adriatic North Region } \\
\text { Adriatic South Region }\end{array}$ & $\begin{array}{c}\text { Estimated } \\
\text { employment rate } \\
60.89 \% \\
47.74 \% \\
55.67 \% \\
58.39 \% \\
48.81 \% \\
\end{array}$ & $\begin{array}{c}\text { Estimated monthly } \\
\text { earning } \\
2785 \\
2811 \\
3703 \\
3495 \\
3524 \\
\end{array}$ & $\begin{array}{c}\text { simulated employment } \\
\text { rate } \\
52.84 \% \\
51.74 \% \\
55.67 \% \\
54.57 \% \\
54.45 \% \\
\end{array}$ & $\begin{array}{c}r \text { market structure } \\
\\
\text { \% change in } \\
\text { employment rate } \\
-15.25 \\
7.73 \\
0.00 \\
-6.98 \\
10.37 \\
\end{array}$ & $\begin{array}{c}\text { Region as reference } \\
\text { simulated monthly } \\
\text { earning } \\
3241 \\
3367 \\
3703 \\
3553 \\
3659 \\
\end{array}$ & $\begin{array}{c}\text { \% change in } \\
\text { monthly } \\
\text { earning } \\
14.07 \\
16.50 \\
0.00 \\
1.64 \\
3.68 \\
\end{array}$ \\
\hline $\begin{array}{l}\text { Central Region } \\
\text { Eastern Region } \\
\text { Zagreb Region } \\
\text { Adriatic North Region } \\
\text { Adriatic South Region }\end{array}$ & $\begin{array}{c}\text { Estimated } \\
\text { employment rate } \\
60.89 \% \\
47.74 \% \\
55.67 \% \\
58.39 \% \\
48.81 \% \\
\end{array}$ & $\begin{array}{c}\text { Estimated monthly } \\
\text { earning } \\
2785 \\
2811 \\
3703 \\
3495 \\
3524 \\
\end{array}$ & $\begin{array}{c}\text { The labc } \\
\text { simulated employment } \\
\text { rate } \\
57.21 \% \\
56.13 \% \\
59.12 \% \\
58.39 \% \\
58.29 \% \\
\end{array}$ & $\begin{array}{c}\text { arket structure of } A \\
\\
\text { \% change in } \\
\text { employment rate } \\
-6.43 \\
14.94 \\
5.84 \\
0.00 \\
16.27 \\
\end{array}$ & $\begin{array}{c}\text { orth Region as refere } \\
\text { simulated monthly } \\
\text { earning } \\
3237 \\
3363 \\
3623 \\
3495 \\
3607 \\
\end{array}$ & $\begin{array}{c}\text { \% change in } \\
\text { monthly } \\
\text { earning } \\
13.97 \\
16.41 \\
-2.21 \\
0.00 \\
2.28 \\
\end{array}$ \\
\hline $\begin{array}{l}\text { Central Region } \\
\text { Eastern Region } \\
\text { Zagreb Region } \\
\text { Adriatic North Region } \\
\text { Adriatic South Region } \\
\end{array}$ & $\begin{array}{c}\text { Estimated } \\
\text { employment rate } \\
60.89 \% \\
47.74 \% \\
55.67 \% \\
58.39 \% \\
48.81 \% \\
\end{array}$ & $\begin{array}{c}\text { Estimated monthly } \\
\text { earning } \\
2785 \\
2811 \\
3703 \\
3495 \\
3524 \\
\end{array}$ & $\begin{array}{c}\text { The labc } \\
\text { simulated employment } \\
\text { rate } \\
47.20 \% \\
46.42 \% \\
50.12 \% \\
49.21 \% \\
48.81 \% \\
\end{array}$ & $\begin{array}{c}\text { arket structure of } A \\
\\
\text { \% change in } \\
\text { employment rate } \\
-29.02 \\
-2.83 \\
-11.06 \\
-18.65 \\
0.00 \\
\end{array}$ & $\begin{array}{c}\text { uth Region as refere } \\
\text { simulated monthly } \\
\text { earning } \\
3157 \\
3280 \\
3542 \\
3417 \\
3524 \\
\end{array}$ & $\begin{array}{c}\text { \% change in } \\
\text { monthly } \\
\text { earning } \\
11.77 \\
14.30 \\
-4.55 \\
-2.28 \\
0.00 \\
\end{array}$ \\
\hline
\end{tabular}




\section{Conclusions}

The labor market performance in Croatia in 2002-2004 varied across individual groups and across regions. Both individual characteristics and regional characteristics played important roles in the determination of employment and earning. Youth, the less welleducated, and women face more difficulties in getting a job with a decent salary. A large part of the difference in regional labor market performance is associated with the difference in human capital endowment.

The combination of the favorable human capital endowment and the well rewarding labor market structure contributes to the good economic performance of the Zagreb Region, followed by the Adriatic North Region; while the combination of the less satisfactory situation of these two results in the backwardness of the development in the Eastern Region. Central Region has the highest employment rate, but the low human capital endowment and the prevalence of the low-paid manufacturing jobs keep the earnings level to the lower end similar to that in the Eastern Region. The individuals have relatively good salaries in Adriatic South Region if they manage to get employed, but the less dynamic labor market and the seasonal nature of many job-demands there lead to the high unemployment.

Both nation-wide education policies and regional specific labor market policies can be effective in enhancing employment and earnings. The entire country will benefit from an improvement in human capital endowment and an appropriate adjustment of labor market structure, and the lagging Eastern Region in particular will benefit more than the other regions.

\section{References:}

Green W.H. (2003), Econometric Analysis, 5th ed. Upper Saddle River, NJ: Prince-Hall.

Gronau R. (1974), "Wage comparisons: a selectivity bias", Journal of Political Economy92, pp.1119-1155.

Heckman J. (1976), "The common structure of statistical models of truncation, sample selection, and limited dependent variables and a simple estimator for such models", The Annals of Economic and Social Measurement 5, pp.475-492.

Lovrincevic Z. and D. Mikulic (2006), "Regional development and social indicators in Croatia", Croatia Living Standards Assessment background paper, mimeo, The World Bank.

Munoz J. (2006), "Visit to Zagreb", Croatia Living Standards Assessment background paper, mimeo, The World Bank.

Nestic D. (2006), "Recent economic developments in Croatia", Croatia Living Standards Assessment background paper, mimeo, The World Bank.

Oaxaca R. L. (1973), "Male-female wage differentials in urban labor markets", International Economic Review, Vol.14, No.3, pp.693-709.

Oaxaca R.L. and Ransom M.R. (1994), "On discrimination and the decomposition of wage differentials", Journal of Econometrics 61, pp.5-21.

Rutkowski J. (2002), "Toward a dynamic labor market and employment growth", Croatia Country Economic Memorandum background paper, mimeo, The World Bank. 


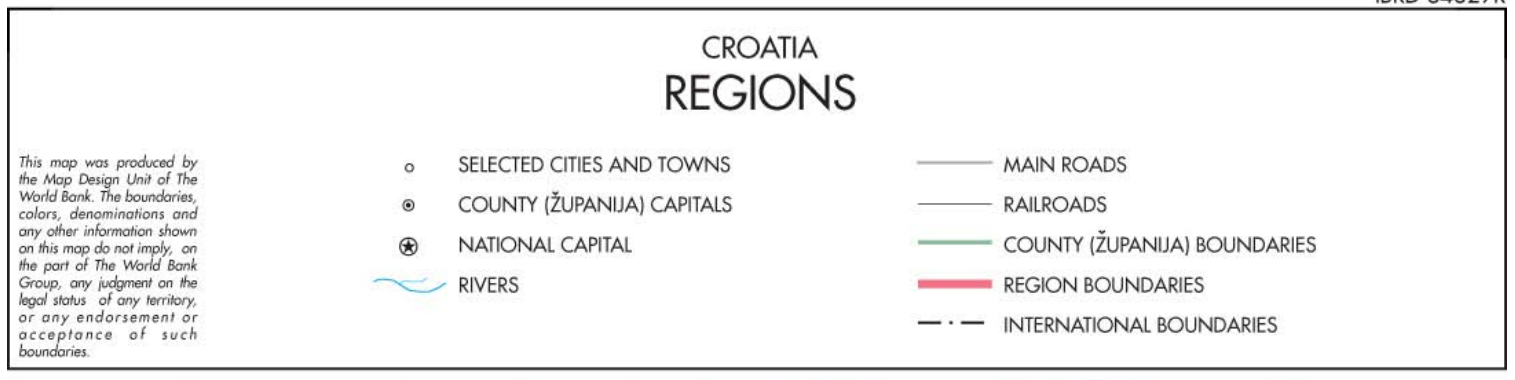

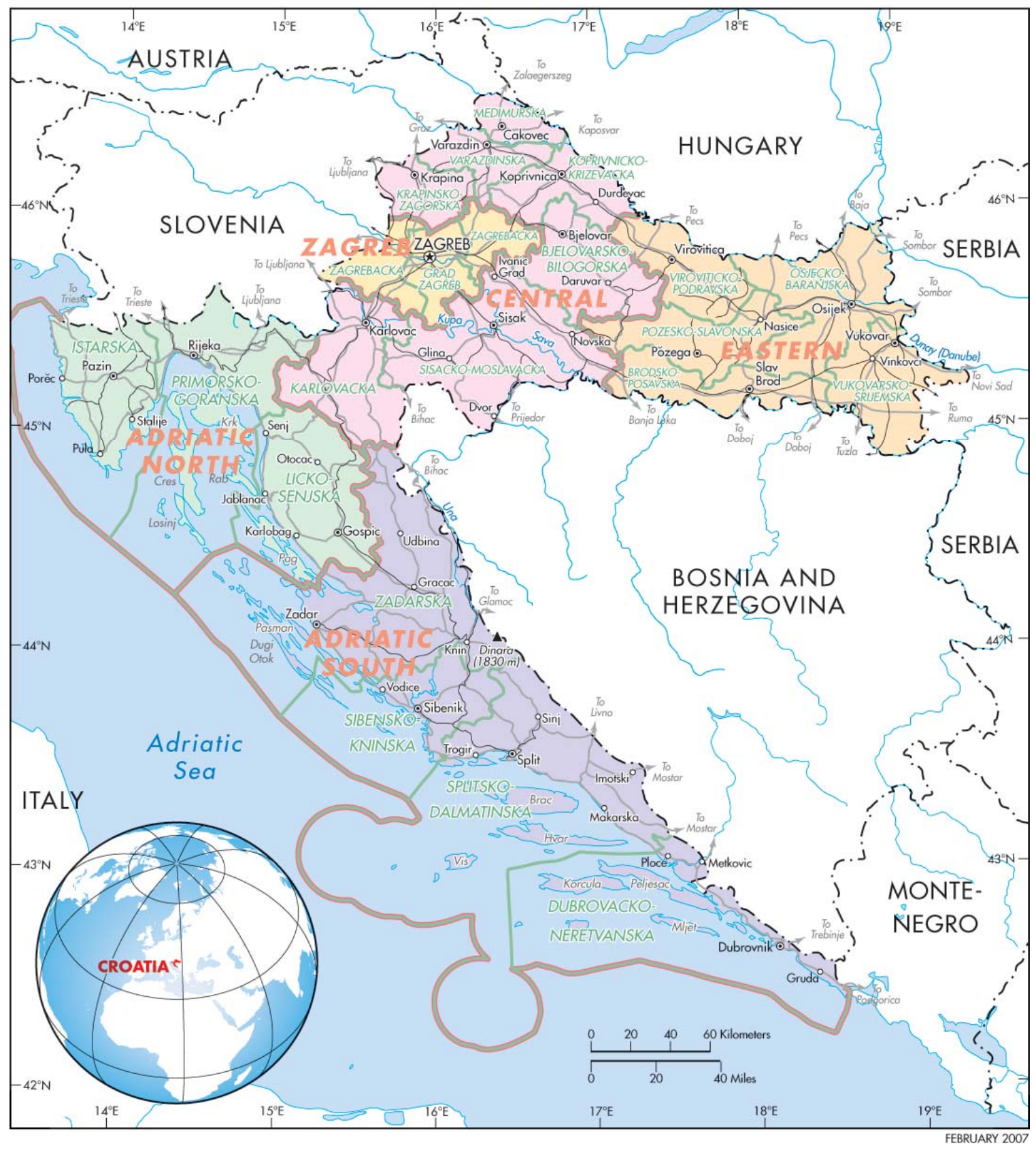

